\title{
The History of a Hunt for Simplicity and Coherence in the Field of 'Ownership', 'Possession', 'Property' and 'Title'
}

\author{
Lisa McClure, * Chantal Stebbings ${ }^{\star \star}$ and

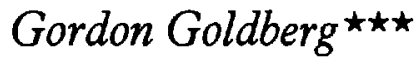

We believe this history to end happily with our not only finding, but vindicating, an old formula which, by its assigning to each of 'possession', 'property' and 'title' a distinct meaning and by its confining the concept of 'ownership' to the second of them, reconciles all the relevant cases, including those on realty with those on personalty, those on the recovery of land with those on the "transfer of title" under the Sale of Goods Act, those on succession with those on sale and those on adverse possession with those on gifts, so that difficulties acknowledged and inconsistencies uncovered in academic writings, such as Megarry $\&$ Wade, to which much reference is made hereafter, unravel and dissolve. Betwixt the beginning and the end, however, this is a tale of mystery and confusion. It is a new tale partly told of the present generation of Legal Examiners of Title in an outpost of Empire, but its mystery and confusion derive from the Old Country and an elder generation of lawyers; and, though it founds on the work of logicians, yet its burden is the survival of obscurity and unreason even, in our deferential and diffident submission and as the Extension of the Tail (10B infra) discloses hereafter, particularly in the mind of one of our critics, through whose kindness and learning we have been introduced to cases significant to our subject whereof otherwise we should have remained ignorant.

\section{The quarry glimpsed}

As well as a moral, which will shortly appear, this story has a theme: no more properly in the Law, than in any other scholarly pursuit, can one draw a line between pure and applied research. For our research was originally so practical as to be seeking grounds for the immediate registration of an instrument under the

\footnotetext{
* Solicitor, Melbourne.

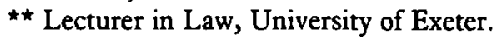

$\star \star \star$ Solicitor, Melbourne (seconded to the Law Department of the University of Reading), from whose discussions on our topic with his recent colleagues in the Strathclyde University Law School, Mrs. Osborne, Professor Miller, Dr. Norrie and Professor Thomson, we have gratefully received (whether or not it shows herein) great benefit.
} 
Transfer of Land Act of Victoria; yet it became, without any deviation or fluctuation, so abstracted as to take us, via various theories expounded or implicit in learned journals, Blackstone's Commentaries and the Sale of Goods Act, back to those of Coke and Bracton.

In 1940, building on the complaint and exertions made fifteen years earlier by Wirens, ${ }^{1}$ Hargreaves published an article, whereof:

"the primary object... [was] to draw attention to the remarkable change which has taken place during the last hundred years in the basic terminology of English land law, the main feature of which is the gradual replacement of the technical apparatus of feudalism by vague conceptions of ownership, the substitution of the 'true owner' for the feudal 'tenant'."'

He opposed this replacement on the ground that the rules of land law:

"simple and coherent as they are, are simple and coherent only because they are based upon a strict regard for the traditional terminology of the law; or, conversely, that the confusion which exists in the text-books on the subject is due not to any confusion in the authorities but to a laxity of language ... If this laxity of language can produce confusion in one branch of the law, it will produce confusion in other branches..."3

Hargreaves' concern was with that branch of land law which deals with recovery against a possessor. The text-books to which he referred included the works of such eminences as Holdsworth, ${ }^{4}$ Pollock, Salmond and Winfield.

That Hargreaves' warning fell on deaf ears was attested by Lord Wilberforce thirty-nine years later in fohnson v. Agnew: ${ }^{5}$

"Learned judges in the Chancery Division and in the Court of Appeal have had great difficulty in formulating a rule and have been obliged to reach differing conclusions. That this is so is due partly to the mystification which has been allowed to characterise contracts for the sale of land, as contrasted

1. "The Plea of the Ius Tertii in Ejectment", (1925) 41 L.Q.R. 139.

2. "Terminology and Title in Ejectment", (1940) 56 L.Q.R. 376. In our respectful submission, there is an example of that, whereof he complains, in $n .70$ infra.

3. Ibid., p. 397.

4. Whose reply (1940) 56 L.Q.R. 479 carries to us no conviction.

5. [1980] A.C. 367 H.L.(E.), 391 and 395. Lord Wilberforce's treatment of realty, as no more mysterious than personalty and on the basis that fundamental principles governing dealings with them are the same, seems to us to reflect the early application of the term 'seisin' to both: see Maitland, "The Seisin of Chattels", (1885) 1 L.Q.R. 324. It has been objected to our reliance on his Lordship's complaint that it related to specific performance of a contract. But, in our submission, a case on a contract of the sale of an interest in land demonstrates the fulfilment of Hargreave's prophecy, of the spread of confusion from one branch of the law to another, more convincingly than would a case merely concerning the nature of that interest, which was already the area of Hargreave's own complaint. 
with other contracts, partly to an accumulated debris of decisions and text book pronouncements which has brought semantic confusion and misunderstandings into an area capable of being governed by principle. I hope that this may be an opportunity for a little simplification. ...

"My Lords, this passage is almost a perfect illustration of the dangers, well perceived by our predecessors but tending to be neglected in modern times, of placing reliance on textbook authority for an analysis of judicial decisions."

The passage, to which his Lordship referred in the last sentence, came from Williams on Vendor and Purchaser. ${ }^{6}$ Thus the consequent fulfilment of Hargreave's prophecy, by confusion's spread beyond the recovery of land to its sale, is the further testimony of fohnson v. Agnew. Ours is that, despite Lord Wilberforce's seizing his opportunity for simplification, the confusion and resulting mystification now extend further to another means of disposition of land, to assents by executors to devises. Our moral, as was the noble and learned Lord's, is the perception of our predecessors.

\section{The chase begun}

Mr. Goldberg drew an instrument intended to effect the transfer of parcels of registered land in Victoria by executors (who had proved the will) from themselves, as the legal personal representatives of the deceased, to themselves and another (who also was named in the will as an executor and trustee but had not proved it), as the trustees of the deceased's estate. Following the lodging of the instrument in the Titles Office at Melbourne, an Examiner objected to its registration. Purporting to rely on an earlier piece by Dr. Stebbings, ${ }^{7}$ he contended that an executor, who claimed to be entitled to hold a legal interest in the deceased's estate as a trustee, must first prove the will, lest otherwise his assent to his own taking of the interest as trustee could not be established.

Mr. Goldberg was duly mystified. His mystification was shared by Miss McClure, who was then his articled clerk. They attended on the Examiner and asked why should an executor, who had not proved, be treated differently from a person who was named, not as an executor, but only as a trustee and who, indisputably (like any other donee of a testamentary gift), in order to take the property, needed the assent only of the executor or executors who had proved. The Examiner countered with the question: if, on his becoming a trustee, an executor, who had proved, indisputably needed to assent in writing to his own taking of real

6. 4th ed., London 1936, in 2 volumes.

7. "The Transition from Personal Representative to Trustee", [1984] Conv. 423. The correspondence, which followed Miss McClure and Mr. Goldberg's persuasion of the Examiner, led to the composition of this article. Of course, the other executor and trustee, since he had not renounced, could have come in and proved pursuant to leave reserved; but that would have entailed the sacrifice as well of money and professional pride, as of time and trouble. 
property in his new capacity, why should it make any difference that the relevant executor had not proved? They replied that in the case of an executor, who had proved, surely the purpose of a written assent was simply to complete his title to the land, which ex hypothesi he now possessed as the deceased's trustee, but which previously he had possessed only as the deceased's personal representative. The Examiner turned to his Megarry $\mathcal{E} W \mathrm{Wde}^{8}$ and read: "This essentially possessory character of title to land is a product of historical evolution and, in particular, of the old forms of action." If (he asked rhetorically and more or less in these words) possession is the essence of title, how can there be any relevant difference between possession and title? But (demurred Miss McClure and Mr. Goldberg) everyone knows that possession is only nine (or eleven) points of the law; ${ }^{9}$ and so title must be the tenth (or twelfth). "Prove it," said the Examiner, "No pun intended." This article is an elaboration and refinement of the arguments, which the Examiner eventually accepted as sufficient to justify the withdrawal of his objection.

When Miss McClure and Mr. Goldberg repeated their demurrer to prominent (but gracious) Counsel, he suggested that its form could be justified only as an exercise of poetic licence. On the other hand he cited in their defence the dictum, "Poetry can communicate before it is understood." They did not scorn this (or any) defence but, further, or in the alternative, and more prosaically, they argued: the value of possession is traditionally expressed only as "in aequali jure potior est conditio possidentis" 10 and as such is no more than the necessary corollary of the maxim, "omnia praesumuntur rite et solenniter esse acta";" for the latter raises the presumption that, the taking of possession having been lawful, the possessor has the property in the piece of realty or personalty in question; but in one case in ten (or even twelve), according to tradition, that presumption needs to be strengthened; and by what, if not the production of title? Counsel having readily assented ${ }^{12}$ to this argument, it set the direction for their researches.

In the administration of deceased estates the change of capacity, to which the Examiner had referred, from personal representative to trustee, is important for many reasons, not least because of the different powers appertaining to each office $^{13}$ and because it is then that the beneficiary of a testamentary trust ceases merely to have a right to have the estate duly administered, ${ }^{14}$ but gains all the

\section{The Law of Real Property 5th ed. (1984), p. 104.}

9. See Shorter Oxford English Dictionary (1984), sub nom. "Point" sb' A III 6.

10. When the rights of action are equal, the position of the party in possession is the more powerful Plowd. 296. For the justification of our translation of jure, see section 10A hereof.

11. All acts are presumed to have been done rightly and regularly: Co. Litt. $6 \mathrm{~b} ; c f$. Kitto J, in Allen v. Roughley (1955) 95 C.L.R. 98, at p. 138.

12. The pun is intended. The barrister concerned was Mr. Pagone of the Victorian Bar. Cf. T. S. Eliot's Dante (1929). Presumably Counsel was implying not that the poetry in Miss McClure and Mr. Goldberg's demurrer was genuine, but that the maxim, unius expressio exclusio alterius, is inapplicable to the writings of a poet such as Eliot.

13. Re Trollope's Will Trusts [1927] 1 Ch. 596.

14. Com'r of Stamp Duties (Q'd) v. Livingston [1965] A.C. 694, at pp. 707-8 (P.C.). 
rights of a cestui que truste. ${ }^{15}$ When dealing with this change of capacity and as was perforce conceded to the Examiner, one encounters two rules: first, that upon the completion of the administration (also called "the clearance") of a deceased's estate by payment of the debts and of the funeral and testamentary expenses, an executor, who has proved the will and whom the will also expressly or implicitly appoints to be a trustee, automatically becomes that trustee; and, secondly, that such an executor is bound to assent, before title to any property may pass to him as trustee.

Further, though the clearance may, in some circumstances, amount to an implied assent, yet Dr. Stebbings ${ }^{16}$ had deduced from the cases that the automatic change of capacity from legal personal representative to trustee is, intrinsically and in principle, quite unconnected with assents or other transfers of title to property. She had concluded also that it is precisely because the automatic change in capacity has no effect on the title to property that, before the personal representative, who has been newly constituted as trustee by the clearance, can as such trustee deal with the property in question, an assent (be it express, or be it implied from conduct in clearing the estate) must be given by the representative to (or in the case of intestacy, where at common law there is no power to assent, ${ }^{17}$ the administrator must take such other steps, as are appropriate for) the passing of title to that property.

But there still remained the question: Does the law have any, and if so what, purpose in requiring an assent (or, for that matter, any other step for passing title) in the case of property which has at all times material been in the possession of the trustee, presently qua trustee, but previously qua the deceased's personal representative? As stated above, ${ }^{18}$ on the answer to that question depended the fate of the instrument of transfer. For, if (as the Examiner had alleged in reliance on $M e g a r r y ~ \mathcal{F} W a d e$ ) there be no relevant difference between title and possession, so that the assent (or other step) can have no real purpose, but exists only as an empty ritual, then there would be no reason why observance of the ritual should not be required as well of an executor who has preferred not to prove, as of one who has chosen so to do. On the other hand, lex non praecipit inutilia; ${ }^{19}$ and so Miss $\mathrm{McClure}$ and $\mathrm{Mr}$. Goldberg were encouraged to press on.

15. E.g., Re Lucking's Will Trusts [1967] 3 All E.R. 726 (Ch.D.).

16. Supran. 7, wherein Eaton v. Daines [1894] W.N. 32, Re Ponder [1921] 2 Ch. 59, Re Cockburn's Will Trusts [1957] Ch. 438, Attenborough v. Solomon [1913] A.C. 76, Re King's Will Trust [1964] Ch. 542 and Re Edroards' Will Trusts [1981] 2 All E.R. 941 are reconsidered and reconciled and academic allegations of conflict between the cases, e.g., Ryder, "Re King's Will Trusts: a Reassessment", [1976] C.L.P. 60, are rebutted.

17. This is implied in 17 Halsbury's Laws 4th ed., 1349 n. 1 and in Gundry v. Brown (1678) Rep. Temp. Finch 370 , where it was held that the position is otherwise in the case of an administrator with a grant c.t.a..

18. See the text at, and following, n. 9 .

19. The law does not prescribe useless actions: Co. Litt. 127b. 


\section{The quarry started (from Sale)}

We have already emphasised Dr. Stebbings' distinct use of the words 'title' and 'property'. In fact, in her very first paragraph, she had spoken of "the transfer of title to the property in question", so that it was apparent that she saw title as an element different from property. However, nowhere did Dr. Stebbings explain what she meant by either term. Did this matter? Miss McClure and Mr. Goldberg were persuaded that it did. For, although the great attraction of Dr. Stebbings' analysis was its reconciliation of the cases and its answer to academic criticisms of the judgments, ${ }^{20}$ yet it had led her to write: ". . . the implied assent has the effect only of making the personal representative hold the asset in question on trust for himself as trustee under the will." ${ }^{21}$ This seemed to involve a rejection of the rule in Selby v. Alston ${ }^{22}$ that, if the legal and equitable estates be commensurate, a person cannot be trustee for himself; and accordingly it suggested to them that Dr. Stebbings had gone astray. Therefore, in exploring the distinction between 'title' and 'property', which Dr. Stebbings had skirted, it seemed likely to Miss McClure and Mr. Goldberg that they would be on the way to discovering the source of an error; and, in that exploration, they saw themselves as possibly taking, by a process of elimination, the first steps to a definition of 'title', which would be capable of distinguishing it from 'possession' and which was thus essential to the proof required of them by the Examiner.

The distinction between 'title' and 'property', albeit primarily in connexion with the apparently disparate activity of the sale of goods, had earlier been drawn by Battersby and Preston. ${ }^{23}$ To them 'property' meant a particular interest (e.g. the fee simple, a life estate, or a term of years - any of which, whether legal or equitable, might be absolute, conditional, terminable, in remainder, or in reversion - or a lien, mortgage, pledge or charge) in or over the relevant land, goods, choses in action, or other chattels. ${ }^{24}$ Their theme was that "in any given situation . . . the phrase 'transfer of property' needs expanding to 'the transfer of such-and-such a title to such-and-such an interest" ", ${ }^{25}$ because "the fundamental rule in the English law of property affecting title is nemo dat quod non habet. ${ }^{\prime 26}$ The

20. See n. 16 supra. On the other hand, as Miss McClure and Mr. Goldberg freely admit, the distinction between 'title' and 'property' was not pertinent to the points there made by Dr. Stebbings. 21. [1984] Conv. at p. 427.

22. (1797) 3 Ves. 339; followed and extended in re Selous [1901] 1 Ch. 921. As to our continuing difference of opinion on whether or not Dr. Stebbings' proposition does conflict with the rule, see section 11 hereof.

23. 'The Concepts of 'Property', 'Title' and 'Owner' used in the Sale of Goods Act 1893", (1972) 35 M.L.R. 268. We justify our reliance on them by what we see as their success in reconciling the cases on Part II of the Sale of Goods Act 1893 and in disposing of the difficulties created by writers such as Atiyah in his Sale of Goods 4th ed., p.. 139 et seq. and Cornish in (1964) 27 M.L.R. 472.

24. In this sense, at least as regards "land or tenements, \&c", "interest' includes 'estate': Co. Litt. 345b, where it is said also to include 'title', but thereafter we shall observe the distinction drawn by Battersby and Preson.

25. (1972) 35 M.L.R., at p. 270.

26. No one gives what he does not have: see, e.g., Sale of Goods Act 1979, s.21(1). 
result of that rule "is that, although a transfer may comply with the legal formalities required for transfer of the interest in question, it may yet fail to take effect because the transferor has no title to transfer." ${ }^{27}$ In other words, the general rule of English law is that a transfer of property gives no guarantee of an indefeasible title to the transferee. In a system where such a guarantee were given, the distinction between title and property would be otiose; hence, perhaps, the frequent semantic confusion between the two. But the English system is one of competing titles, which makes the distinction fundamental; for, though the interest transferred may be absolute, yet save in special cases, such as (at common law) of goods sold in market overt and of bills of exchange acquired by a holder in due course and (by statute) of land registered under the Torrens system, the title to it can never be more than relative; and, because of its mere relativity, "title to property is protected by the possessory actions, which require only that the plaintiff have possession or the immediate right to possession ... [so that] mere adverse possession of property confers a title, which is good against the whole world, except the person who can prove a better title, that is to say, a person with a continuing prior title." 28

The strength of this thesis and its applicability to both real and personal property can be briefly illustrated by reference to two cases which are not included among those discussed by Battersby and Preston and which, because they are not, enhance the argument. In Palmer v. Palmer, ${ }^{29}$ which was an action for the recovery of land, the statement of claim alleged merely that the plaintiff was entitled to possession of land as heir-at-law of Mary Brown, who had died seised in fee of the premises and intestate. It was held that the defendant was entitled as of course to particulars shewing the links of relationship on which the plaintiff relied as constituting him such heir. Despite its brevity, the report makes clear that the contest between the parties was only to prove a title derived from a person who had had possession prior to the possession of the rival claimant or of the rival's predecessor in title. The same revelation is to be found in the longer report of Moffat v. Kazana ${ }^{30}$ which relates the finding by the defendant in his bungalow of a biscuit tin containing money. He was sued by the executors of the deceased who had preceded him as owner and occupier of the bungalow. They proved merely (but with corroborative detail to give verisimilitude to the narrative) ${ }^{31}$ that the predecessor had had the tin with him, when he moved into the bungalow, and had retained it, until he moved out; and they consequently won.

There is no suggestion that in those rare cases, where English law does guarantee title, there is a difference in the form of action brought by the owner to protect his right of possession. But there is a considerable difference in the

27. (1972) 35 M.L.R., at p. 269.

28. Ibid.. Our view on adverse possession is in the text after $n .88(1)$ infra and in section $10 \mathrm{C}$ below.

29. [1892] 1 Q.B. 319 (Q.B.D.).

30. [1969] 2 Q.B. 152 (Assizes).

31. As prescribed in Sir William Gilbert's The Mikado, Act II. 
pleadings. Where goods have been bought in good faith in market overt, ${ }^{32}$ or in the case of land under the Torrens system bought in good faith from the registered proprietor, ${ }^{33}$ the buyer alleges only the relevant purchase; and likewise a party, who has obtained a bill of exchange in such circumstances as to become its holder in due course, ${ }^{34}$ alleges only the relevant acquisition. By the one simple allegation the owner asserts both his property in, and title to, the asset in dispute. There is thus no distinction between the two nor any need of a detailed history, such as was forced out of the Plaintiff in Palmer v. Palmer and as was determinative of the question in Moffat v. Kazana. However, as is the logical consequence of competition between titles and in contrast to a transaction in market overt, or with a registered proprietor, or whereby one becomes a holder in due course, in neither Palmer nor Moffat was there a single obvious and essential event, with occurrences before which the court did not need to be concerned. In both of them the starting point of the story told by each side depended on the commencement of that told by the other.

From all of this it follows that title is the means whereby one shows that one has a better right to possession of the property in issue than does one's rival claimant; and title is ordinarily ${ }^{35}$ what one receives from one's predecessor in title; and so in all ordinary ${ }^{35}$ transfers of property, real or personal, moveable or immoveable, corporeal or incorporeal, in theory the basic question does not vary: How does the transferor prove what title he has received and can therefore pass on? In practice, however, the importance attached to that question does vary with the nature of the property to be transferred. With land, ships and company shares, where documentary title is the norm, investigation of the validity (including the completeness) of the transferor's title must be expected. It is otherwise with goods in general, where the transferee can reasonably be expected to accept just the evidence ${ }^{36}$ afforded by the transferor's possession apparently as owner, an expectation encouraged by the exceptions to the nemo dat rule which reduce the risk of bad titles. ${ }^{37}$

With this analysis, Miss McClure and Mr. Goldberg were favourably

32. On which the Common Law is embodied in the Sale of Goods Act 1979, s.22(1).

33. As provided by the Land Registration Act 1925, s.18.

34. As provided by the Bills of Exchange Act 1882, s.38(2).

35. I.e., otherwise than in, or other than, those exceptional cases where title is created for the first time as, e.g., by Crown Grant or invention, or is extinguished and recreated as, e.g., by sale of goods in market overt, by the sale of registered land by the registered proprietor thereof, or by the constitution anew of a holder in due course of a bill of exchange (see n. 32 et seq. supra), or by the operation of the Limitation Act 1980, ss.3(2) and 17, or by accession, confusion or specification: Bracton (ed. Thorne, Camb. Mass. 1968, vol. 2, pp. 45 et seq.) who on this is followed by Blackstone (2 Com. pp. 404-5), though the latter does not use the word, "specification", and indeed treats the process as a variety of accession.

36. See per Cozens-Hardy MR, in re Atkinson and Horsell's Contract [1912] 2 Ch. 1, at p. 9 and per Taylor J., in Allen v. Roughley (1955) 94 C.L.R. 98, at p. 144.

37. E.g., Sale of Goods Act 1979, ss. 22 to 26 (both inclusive). 
impressed. For, like Dr. Stebbings', in its own field it reconciled the cases ${ }^{38}$ and resolved the difficulties created by other academics. ${ }^{39}$ Furthermore, Miss McClure and Mr. Goldberg felt that, with its aid, they had made progress; for (pace Megarry $\mathcal{E} W$ Wade), ${ }^{40}$ far from possession being of the essence (as distinct from being merely evidence) of title, it had been revealed that a right of possession was the effect of title and so, conversely, title was the cause of such a right; and surely there are no more logically distinct concepts than cause on the one hand and effect on the other. This conclusion was enough to satisfy the Examiner.

\section{Sir Mackenzie Chalmers, his Gest ${ }^{41}$}

But the matter could not, with propriety, be allowed to rest there. For, rather more than half way through their article, ${ }^{42}$ Battersby and Preston were found contending that, in the Sale of Goods Act 1893, far from being contrasted, each of the terms, 'property' and 'title', was so used as to have the same meaning as the other. In view of Chalmers' reputation as a draftsman, none of us felt this could be right. Furthermore, the formula derived from Battersby and Preston (supra) begs the question of what is the origin of the title that is derived from one's predecessor in title. Not only propriety, but practicality, required the research to be continued; for assents are frequent occurrences in legal practice and sales even more so; and continuing doubt and confusion as to what is involved in them would be bound to lead to more mystification and trouble sooner or later.

That, in fact, Chalmers understood property to be something other than title, was the first and lasting impression made on each of us by the headings in Part II of the Sale of Goods Act 1893, ${ }^{43}$ when, in our respective undergraduate studies, we were introduced to them. The heading of the whole Part, which comprised sections 16 to 26 (both inclusive) was "Effects of the Contract". ${ }^{44}$ The subheading covering the first five of those sections was "Transfer of Property as between Seller and Buyer" and that of the remaining six was "Transfer of Title". Of the latter sections, four ${ }^{45}$ concerned the acquisition of, and one ${ }^{46}$ the failure to

38. Singer Manufacturing Co. v. Clarke (1879) 5 Ex.D. 37; Burrowes v. Barnes (1900) 82 L.T. 72; The Winkfield [1902] P. 42; Clayton v. LeRoy [1911] 2 K.B. 1031; Rowland v. Divall [1923] 2 K.B. 500; Buller $\mathcal{E}$ Co. v. Brookes Ltd. [1930] All E.R. Rep. 534; Bishopsgate Motor Finance Corp. Ltd. v. Transport Brakes Ltd. [1949] I K.B. 327; Farvis v. Williams [1955] 1 W.L.R. 71; Newtons of Wembley $L t d$. v. Williams [1964] 2 All E.R. 135, on appeal [1965] 1 Q.B. 560; Car \& Universal Finance Ltd. v. Caldwell [1965] 1 Q.B. 525; Provincial Bank Ltd. v. Ainsworth [1965] 1 A.C. 1175; and Belvoir Finance Co. Lid. v. Stapleton [1971] 1 Q.B. 210.

39. Atiyah, The Sale of Goods 4th ed. (1971), pp. 13, 139 and 207; and Cornish, "Rescission without Notice", (1964) 27 M.L.R. 472.

40. See the text at and n. 8 supra.

41. See Shorter O.E.D. (1984), sub nom. "Gest" sb. ${ }^{1} 1$.

42. (1972) 35 M.L.R. at p. 280.

43. Reproduced in Part III of the Act of 1979, which in Part VII by s.63(2) repealed the Act of 1893.

44. The contract referred to is a contract of sale of goods: s.1(1) of the Act of 1893.

45. S. 22 - sale in market overt; s. 23 - sale under voidable title; $s .25$ - sale by seller or buyer in possession after a sale by, or to, him; and s.26 - effect of writs of execution.

46. S.21 - general provisions relating to sale by person not the 'owner' thereof. 
acquire, 'title' by persons who dealt with those who themselves lacked any, or had only a defective, 'title' to the goods in question. The other, in a single instance, provided for the destruction of a title so acquired and the consequent revesting, in the previous 'owner', of the property in the relevant goods. ${ }^{47}$ Thus the 'title', which was the subject matter of those sections, is something which, if paid for, can be acquired by the 'buyer' even though it has not previously been the 'seller's', whereas the subject matter of the former sections, ${ }^{48}$ i.e., 'property', is something which, as the relevant sub-heading made clear by its reference to transference "between Seller and Buyer", was conceived of as being capable, even if paid for, of being acquired by the 'buyer' only if it has previously been the 'seller's'. In other words, 'property' is something which, if it is to be transferred from the seller to the buyer, must have been the seller's in the first place, while 'title' is something which need not have been the seller's but which, if not, can be constituted in the buyer by his transaction with the seller, provided the transaction be given that effect by the law as then embodied in the latter sections. Thus, while 'title' appertains especially to the law, 'property' pertains especially to the parties.

In other words the 'property' which is transferred between the seller and the buyer as an effect of the contract of sale can be nothing else than 'proprietorship' or 'ownership', i.e., that quality by which the goods are the seller's and then the buyer's. Further, this is at once the explanation, and the necessary implication, of the second sentence of section 1(1) of the Act of 1893,49 which read:

"A contract of sale of goods is a contract whereby the seller transfers or agrees to transfer the property in goods to the buyer for a money consideration, called the price. There may be a contract of sale between one part owner and another."

For, unless it be assumed that the seller is the 'owner' of what is being sold, what could have been the point of the second sentence? This assumption that the seller be, and be agreeing to cause the buyer to become, the owner of what is being sold also explains the confinement of the definition of property in section $62(1)$ of that Act ${ }^{50}$ to the "general property in the goods" and the exception therefrom of a mere "special property"; otherwise the contract could be merely for the grant or the assignment of a security, ${ }^{51}$ to which the Act was never intended to apply ${ }^{52}$ and to which many of its provisions were quite inappropriate. ${ }^{53}$

47. S.24 (repealed, and not reproduced, by the Act of 1979) - revesting of 'property' in stolen goods on conviction of the offender.

48. S.16 - goods must be ascertained before property can pass; s.17 - property passes when it is intended to pass; s. 18 - rules for ascertaining that intention; s.19 - reservation of right of disposal indicates a contrary intent; and s. 20 - risk prima facie passes with property.

49. Reproduced as s.2(1) and (2) of the Act of 1979.

50. Now to be found in s.61(1) of the Act of 1979.

51. The Odessa [1916] 1 A.C. 145 (P.C.), at p. 158 et seq; Attenborough v. Solomon [1913] A.C. 76 ((H.L.(E.)), at p. 84 per Lord Haldane LC; Rose v. Matt [1951] 1 All E.R. 361 K.B. Div. Ct., at p. 362; and which includes a mere lien-Bridges v. Hawkesworth (1851) 21 L.J.Q.B. 75, at p. 76 per Patteson J. 52. S.61(4), reproduced as s.62(4) of the Act of 1979.

53. E.g., ss.14 and 15. 


\section{Sir Edward Coke, his Gest}

But the effect (whether actual or intended) as much of a contract, dealing with special property, as of one which fell within the Act, would still be what Battersby and Preston described as "a transfer of property". Thus we can see that this description needs expansion (even beyond that given to it by them) ${ }^{54}$ to "a transfer of such-and-such a title to the property in such-and-such an interest", the title being an appurtenance of the law and the property being the quality of the interest which makes us its owner, i.e., makes it ours; and we have previously seen ${ }^{55}$ that the right of possessing a particular 'interest' is the effect of 'title', so that 'title' is the legal cause of that right. Therefore, title is the legal cause of possessing what is ours or, in the words of Coke, "titulus est justa causa possidendi quod nostrum est". ${ }^{56}$

A recognition of the continuing validity of Coke's definition would have avoided the circularity of which Megarry \& Wade is guilty in Part $3^{57}$ (where the subject is "Ownership, Possession and Title") of the third chapter, headed "Estates". There the authors state: "Title to land ... depended on the better right to possession (seisin) rather than vice versa" 98 and "Ownership, as between two rival claimants, is the better right to possession." 59 If those two statements were correct, surely there would be no difference between ownership and title; and further, if title itself

54. See the text at $\mathbf{n} .25$ supra.

55. See the paragraph comprising the text following $\mathrm{n} .37$ supra.

56. 1 Inst. $345 \mathrm{~b}$; and see section $10 \mathrm{~A}$ hereof.

57. Pp. 102 et seq..

58. Ibid., p. 104 ad fin.. In the light of Maitland's work, supra n. 5, we doubt if (at least in the old common law, i.e., at the latest, before Taylor d. Atkyns v. Horde (1757) I Burr. 60) seisin meant more than possession of which the law took account procedurally or substantively. See also his Forms of Action at Common Law ed. Chaytor \& Whittaker (Cambridge 1968), pp. 17-8. On p. 24 thereof "seisin, we may observe, is not conceived as a descendible right"; on p. 36 the distinction "between property and possession" is drawn as that "between ius and seisina"; and on p. 45 it appears that "Littleton, who wrote between 1474 and 1481, in section 324 says in effect that a termor is not seised but is possessed. But in section 567 he himself slips into speaking of the termor as seised." In our submission, Littleton's inconsistency may reflect only that the confinement of seisin to realty has been complete only since, not necessarily during, the 15th century: $c f$. the text preceding n. 59(2), infra. On p. 38, speaking of the 13th century, Maitland had said:

"[W]e have Bracton discussing the problem whether the termor is not seised of the land.

Undoubtedly his lessor is seised, and if the termor be ejected by a third person the lord can

recover the land from the third person as from one who has disseised him; - but the termor also

is getting protection - what are we to say, can two persons at one and the same time be seised or possessed of the same acre in two different rights? . . [ [I]n the fifteenth century there will be a differentiation of terms, the termor will be possessed, the freeholder will at the same time be seised. ... Then 'seised' will come to use the right competent to the freeholder, 'possessed' will imply the right to use the writ of trespass."

For the old lawyers, perhaps the distinction was between seisin in the sense in which we now use possession, i.e., the sense in which we now plead that a landlord is in possession by his tenant or that the tenant himself is in possession, on the one hand, and mere use and occupation on the other. See also the text at n. 68(2), infra. For a recent case on the weighty nature of possession, see Marsden v. Miller, The Times, 23 January 1992 (C.A.).

59. Ibid., p. 106. 
were essentially possession (as they also assert), ${ }^{60}$ surely there would be no need to talk of ownership or title or, indeed, of anything other than possession. That false conclusion and the utter confusion it entails appear in another of the learned authors' sentences: ${ }^{61}$

"Any distinction between seisin and possession as the basis of title is obscured by the well-established rule that possession of land, if exclusive of other claimants and not otherwise explained, is evidence of seisin in fee simple."

For, from their definition of "seisin" as the "right to possession", when taken with the standard definition of evidence as what tends to prove the existence of a fact (rather than as a constituent of the fact itself), ${ }^{62}$ it follows that, contrary to the learned authors' implication, the "well-established rule" does not necessarily say anything about "the basis of title"; and, contrary to their assertion, far from obscuring the distinction between possession and right to possession the rule clarifies it. ${ }^{63}$

There are other difficulties with Part 3 of Chapter 3 of Megarry $\&$ Wade. The authors say: ${ }^{64}$

"Possession by itself gives a good title against all the world, except someone having a better right to possession."

It will be recalled that by them the "right to possession" is called "seisin"; and so, from their later phrase "the earlier and therefore the better seisin", ${ }^{65}$ we learn that for them a better right to possession means an earlier right to possession. This is consistent with their theme of possession's being the be-all and end-all both of title and of ownership; and hence one would expect that, if X proves himself to be the successor in title to $\mathrm{O}$ and $\mathrm{O}$ to have been in possession before $\mathrm{S}$ or any predecessor

60. See the text at n. 8 supra.

61.Ibid., p. 105 ad fin.. Authority for the "well-established rule", to which they refer, can be found in Asher v. Whitlock (1865) L.R. 1 Q.B. 1, at p. 6: "The fact of possession is prima facie evidence of seisin in fee", per Mellor J, whose reference to the "rightful owner" at p. 7 is, in the context of his whole judgment, obviously to the vague conception of anyone who could produce evidence of title better than naked possession. Cf. Cockburn, CJ's reference, ibid., at p. 5 to "the person who can show a good title" and $\mathrm{nn} .70(1)$ and $2(2)$ infra.

62. See Shorter Oxford English Dictionary (1984), sub nom. "Evidence" sb. 5 \& 6. Contrast, ibid., sub nom. "Basis" 3.

63. Of course, if the rule is using 'seisin' in the sense set out in n. 58 supra, it states only that possession is evidence of an estate in fee simple in the possessor, whether lawful or naked, as to the latter whereof see the text at nn 99(1) and 67(2) infra and those notes themselves.

64. P. 103 ad fin.

65. P. 105 ad init. 
in title of $S, X$ must recover against $S$, if $S$ is in possession. But later still we are told: 66

"Suppose that, while $S$ is still in undisturbed possession, $O$ dies and by his will leaves all his land to $\mathrm{X}$. If $\mathrm{X}$ acts in time he can obtain the land by asserting $O$ 's superior title. But here $S$... can compel X to prove his title, and if X's title, as derived from $\mathrm{O}$, is subject to a jus tertii then $\mathrm{S}$ can plead it."

This proposition is undoubtedly true. ${ }^{67}$ But it is hardly consistent with the first quotation in this paragraph nor with a concept of ownership which is not to some degree independent of possession. ${ }^{68}$ The same inconsistency is found in the following sentence from the same Part: ${ }^{69}$

"Where the possession is truly adverse, there is little merit today in preserving for this purpose [i.e., the founding of title] any distinction between seisin and possession."

The introductory modification was introduced because "possession by a tenant or an agent is no foundation for a title against the landlord or the principal." But it does not explain to what the possession must be "truly adverse". Surely it must be adverse to the owner's interest, whatever it may be, by denying him its possession; and, if so, that interest must be his independently of its possession by him. ${ }^{70}$ Further, it must be his pursuant to his right to possession and, if (as says Megarry

66. P. 107 ad fin.. For our explanation see the text at no. 93(1) infra; and $c f$. also the text preceding n. 73(2) infra and that note itself.

67. Wiren, supra $\mathrm{n} .1$ and the cases there cited.

68. Megarry $\mathcal{E}$ Wade's explanation at p. 108 ad init. is that it "is self-evident, for otherwise $S$ would have no protection against anyone purporting to claim through $O$. ." But this says no more than that the law is supported by practical policy. It does nothing to reassure us concerning "the logical development of clear principles" on which, in the preface to the first edition (1957) reproduced on p. ix of the fifth, we were assured that "[i]n the main, the English law of real property rests". Is such reassurance important? "It is sufficient to answer that this is a question of title, of which the whole form and structure is built on theory ... strict adherence to theory is indispensable for the best of all practical reasons, that the theory affords the only means of solving with certainty and consistency those numerous questions which would otherwise become the subject of loose and arbitrary adjudication.' The value of a theory depends, however, on the clarity and coherence of the language in which it is expressed": Rudden, (1964) 80 L.Q.R. 63, at p. 72 quoting, and adding to, Lord Fullerton in the Inner House of the Court of Session in Young v. Gordon's Trustees (1847) 9 D. 932, 950.

69. P. 106 ad init..

70. This is consistent with the Limitation Act 1980, which does not define 'adverse possession', otherwise than by requiring in its 1 st Sched., para. $8(1)$, merely possession by "some person in whose favour the limitation period can run." At p. 1034 Megarry $\&$ Wade say: "Today [adverse possession] merely means possession inconsistent with the title of the true owner, and not, e.g., possession under a licence from him or under some contract or trust." We cannot see where, if at all, the learned authors define "true owner"; nor can we see how the use of the term is consistent with their statement at p. 108 ad med. that "English law knows no abstract ownership" and, despite diffidence and with deference, submit it to be an example of "the vague conceptions of ownership", whereof Hargreaves complained in the quotation in the text at $\mathrm{n} .2$ supra. 
$\mathcal{F}$ Wade) that right is called seisin, then the distinction between seisin and possession is still important.

\section{Sir Francis Bacon, his Gest}

Whatever its internal inconsistencies, Megarry $\mathcal{E}$ Wade is consistent with Battersby and Preston in its quotation with approval ${ }^{71}$ from the judgment delivered by Lord Diplock in Ocean Estates Ltd. v. Pinder: ${ }^{72}$

\footnotetext{
"At common law ... there is no such concept as an 'absolute' title. Where questions of title to land arise in litigation the court is concerned only with the relative strengths of the titles proved by the rival claimants."
}

However the lack of a concept of an "absolute title" in the sense of a title recognized as good against the whole world is seen to be quite consistent with Coke's recognition of ownership, when one recalls that Coke defined title as justa causa, i.e., as a cause recognized by law. For English law acknowledges that the absolute is beyond man's ken, including and in particular the facet of the absolute called 'truth'. This acknowledgment can be found in Bacon's"3 essay, "Of Truth", published in 1597 wherein, without Evangelical warrant, when "Pontius saith unto him, "What is truth?" "74 the speaker is depicted as "jesting"; and 369 years later its cynicism was repeated in The Wagon Mound (No. 2): ${ }^{75}$

"In the present case the evidence led was substantially different from the evidence led in The Wagon Mound (No. 1) and the findings of Walsh J are significantly different. That is not due to there having been any failure by the plaintiffs in The Wagon Mound (No. 1) in preparing and presenting their case. The plaintiffs there were no doubt embarrassed by a difficulty [of countering an allegation of contributory negligence] which does not affect the present plaintiffs."

Obviously, if the evidence on which the court has to base its decision is

71. P. 104 ad med..

72. [1969] 2 A.C. 19 , at pp. 24-5 (P.C.).

73. Who, after all, became Lord Chancellor under James I. The healthy cynicism, to which this Essay bears witness, may perhaps be considered, first, in the light of Shakespeare's Hamlet (wherein the eponymous hero finds the truth only with supernatural aid and even then not to much avail), to be typical of the Age and, secondly, to be at least as much the cause for the disavowal of torture by Coke in 3 Inst. 35 as, if not more than, was the concern for the liberty of the subject, to which it was attributed by Holdsworth in 5 H.E.L. 194. For, if no certainty as to the truth be obtainable, there can be no purpose to torture other than the unprincipled punishment of the accused before his conviction. Furthermore, this impossibility of certainty justifies the common law's preference for the adversarial, to the inquisitorial, method of trial; for, quite apart from the inquisitor's liability to blindness from the dust of the arena, it is a waste of public resources for the court to pursue the unobtainable.

74. fohn xviii, 38.

75. [1967] l A.C. 617 , at p. 640 per Lord Reid (P.C.). 
dependent on the will of the parties, that decision cannot fairly be considered absolute, but may fairly bind only the parties; and this is true as much of a decision as to title as of a decision on any other matter. Hence, at Common Law, unlike in Ecclesiastical or Admiralty Law or by Statute, no justa caus $a$ can be absolute so as to entitle its promoter to a decree in rem (as distinct from inter partes); and hence English courts cannot recognize the 'true owner' of land or goods who thus, in English law and in Hargreaves' words ${ }^{76}$ and in spite of Megarry $\mathcal{E}^{\prime} \mathrm{Wade}$ 's reliance on him, ${ }^{77}$ can never be more than a "vague conception". Nonetheless, though it be convenient to talk as do Lord Diplock, Battersby and Preston and we ourselves of "titles", their competition and their relative strengths, in each case the court actually asks which of the parties, on the balance of probabilities has by evidence, including perhaps priority of possession, shown the title to be in him; and, if he be not the current possessor, then that possessor is in not by title, but by tort. ${ }^{78}$

\section{The quarry viewed}

Once it is seen that title, however relative, is a concept quite distinct from property, it can be perceived that we may have the property in an interest, i.e., the interest, whether personalty or realty, may be ours but, because we lack or lose title to it, we do not have the cause recognized by law of possessing it, so that our property in that interest becomes of no avail. Obvious examples of such loss are the extinction of title by the operation, expressly, of sections 3(2) and 17 of the Limitation Act 1980 following the expiry of the relevantly prescribed period of adverse possession and, implicitly, of section 38(2) of the Bills of Exchange Act 1882 by virtue of the privileges given to a holder in due course. Equally obvious instances of such loss are the situations now covered by sections 22(1), 24 and 25 of the Sale of Goods Act 1979, of sale of stolen goods in market overt, of resale of goods by a seller thereof, who has retained their possession after their previous sale by him, and of sale of goods by a buyer thereof, who has received the possession thereof but to whom the property therein has not yet passed. Other instances, but to be found only in the cases, are accession, confusion and specification, where loss of title to the property in goods necessarily follows the loss of the identity of the goods. ${ }^{79}$

On such loss of title, no one can challenge the possession of the adverse possessor or buyer or other acquirer of the relevant interest. Because the just cause of possessing that interest lies in no one else, that cause must lie in the adverse possessor or buyer or other acquirer; and, since Coke's definition of title implies

76. Quoted in the text at $\mathrm{n} .2$ supra.

77. At p. 1034; see n. 70 supra.

78. See the text at and n. 2(2) infra. We stress that in this context 'tort' has a meaning wider than does 'wrong' - see n. 72(2) infra - and (despite the risk of being repetitious) that, in any event, the respective findings of title and tort bind only so far as the doctrines of res judicata and issue estoppel allow.

79. Re Bond Worth Ltd. [1980] Ch. 228; Borden (U.K.) Ltd v. Scottish Timber Products Ltd. [1981] Ch. 25; re Peachdart Lid. [1984] Ch. 131; and Indian Oil Corpn. v. Greenstone Shipping S.A. [1988] Q.B. 345. 
that possession is the cardinal indicator of property, unchallengeable indefinite possession must be the equivalent of property. Thus, with the title, the adverse possessor or the buyer has gained also property ${ }^{80} \mathrm{It}$ will have become evident that we respectfully agree with Megarry $\& W$ Wade in its disavowal of the conception of a "parliamentary conveyance" and in its analysis of the process as the extinction of one title and the arising of a new. ${ }^{81}$ However, following Chalmers, the relevant sub-heading of the Sale of Goods Act 1979 still reads, "Transfer of title"; and we cannot forbear to defend one whom we so greatly admire. Though title is relative in the sense that a court is concerned only to decide which side has produced stronger evidence of title, yet, as an ideal, the title to the property in any interest, whether personalty or realty, is a unity and is unique; ${ }^{82}$ and it is not unreasonable to depict the loss of such a unity by one person and the acquisition of an identical unity by another as the transfer of the same unity.

We pointed out earlier ${ }^{83}$ a question, begged by Battersby and Preston, is the origin of the title that is derived from one's predecessor in title. In the twenty-sixth chapter of the second book of his Commentaries on the Laws of England, ${ }^{84}$ Blackstone considers property to be transferred and continued by gifts, contracts, testaments, legacies and administrations, but to be "acquired by occupancy" in such forms and by such means: as the seizure to one's own use of goods, which belong to an alien enemy ${ }^{85}$ or which have been abandoned by the last proprietor; ${ }^{86}$ as the capture of animals ferae naturae $;{ }^{87}$ as accession; as confusion; and as labour and invention, e.g., copyright. Blackstone begins that chapter:

"We are next to consider the title to things personal, or the various means of
acquiring, and of losing, such property as may be had therein..."

80. Cf. re Atkinson and Horsell's Contract [1912] 2 Ch. 1, at p. 9 per Cozens-Hardy MR infra. It has been objected, by the anonymous donor referred to in $\mathrm{nn}$. 93(1) and 97(1) infra, that our notion of the dispossessed's having a property to which he has lost the title, so that it is of no avail and exists only as (to quote the objector) "a property in nubibus, seems a strange one." But, in our respectful submission, it is strange only if one is limited by the concept of absolute title. Once one accepts, as does English law, that title is a matter of evidence between the parties to the litigation, and only between them, it is not strange if I cannot prove my right to possess what is mine. After all, there is obviously much room for speculation as to what would have happened in Felthouse v. Bindley (1862) 11 C.B.N.S. 869, if it had been the nephew suing the uncle, rather than the uncle suing the auctioneer: see $35 M . L . R .489$ et seq.; 38 M.L.R. 198; and 105 L.Q.R. 462.

81. Op. cit., p. 109; cf. Re Atkinson and Horsell's Contract, supra n. 80. Despite what Megarry \& Wade says at p. 1053, we respectfully maintain that even s. 75 of the Land Registration Act 1925 is consistent with the arising of a new title in, rather than the conveyance of the old title to, the usurper after the prescribed period: see the text following $n .82(2)$ infra.

82. See the text at $\mathbf{n} .78$ supra.

83. In the text following n. 42 supra.

84. (Oxford, 1766) pp. 400 et seq.. The emphases in the sentence quoted by us below are the author's. 85. So far as we understand the current laws of booty, prize and war, such goods, if lawfully seized, would now belong to the Crown.

86. The postulated abandonment would have been of the abandoner's general property. in the goods, so that the goods ceased to be his; and, since his title to the goods was simply the just cause of his possessing what was his, it follows that, with the property, was abandoned also the title. Hence 
whence it is plain that, with the acquisition by occupancy of property, one also acquires title. ${ }^{88}$ But we have already perceived that, title being a concept separate from property, one may have property without title; and once it is seen that property in an interest is merely a quality of that interest, which if present, makes that interest ours, we can perceive further that, even though we have the property in an interest, in other words, are the owners of it, so that our transfer of that interest will render the transferee its owner in his turn, yet that transfer may give the transferee nothing which a court will recognize as a legal cause of his possessing it. Even so, it does not follow that a court will compel the transferee to surrender what he has received from us to just anyone.

Suppose we adversely possess a piece of land and convert a chattel and, before the expiration of either of the respective limitation periods, purport to sell and convey that land and to sell and deliver that chattel. Though we cannot possess more than we have taken, ${ }^{89}$ yet, because we ourselves cannot qualify the wrong constituted by the adverse possession, ${ }^{90}$ or by the conversion, we are generally presumed to have adversely possessed ${ }^{91}$ or to have converted and, if the contract be open, to have agreed to sel192 the fee simple in the land and the corresponding interest (i.e., what Chalmers called "the general property") in the chattel. If a complete stranger to the land or chattel challenges the buyer's possession thereof, the challenger will not succeed in any action in court, because the challenger will not be able to prove that the buyer has done him any wrong. Nor will a challenger who relies on a conversion or an adverse possession, which had lasted for less than

abandoned goods cannot be stolen: $R$. v. Thurborn (1849) 1 Den. 387 (C.C.R.). Hence also the abandonment of land by a tenant will lead (as a deemed surrender) to the destruction of the leasehold estate by its merger in the reversion but, because of the contractual element in a lease, only with the consent, express or implied, of the lessor: Oastler v. Henderson (1877) 2 Q.B.D. 575 (C.A.). Furthermore, as stated by Megarry $\& W$ Wade at p. 1036, par. (c) an adverse possessor can abandon the interest he has arrogated, so that a subsequent squatter cannot count the period of the first adverse possession against the person originally dispossessed. We respectfully differ from its learned authors in their implication that, if there be no gap between one adverse possession and another, there can be no abandonment, but only dispossession of the first adverse possessor by the second. In our submission the effect of the second adverse possession depends on the state of mind of the first adverse possessor, so as to determine whether he has been ousted from or otherwise deprived of possession or simply abandoned it. See further n. 97(1) and the text at and n. 3(2) infra.

87. Hence one cannot steal a wild creature not tamed nor ordinarily kept in captivity, or the carcase of any such creature, unless it has been reduced into possession by or on behalf of another and possession of it has not since been lost or abandoned, or unless another is in the course of reducing it into possession: Theft Act 1968, s.4(4).

88. See further n. 35 supra.

89. Thus, if a usurper or squatter occupies land that is let, then, until the expiry, surrender or other determination of the lease, his possession is adverse only to the interest of the tenant, whose obligations to the landlord are not thereby affected (there being no assignment of the lease), so that time does not begin to run against the landlord until the lease be determined: Oxford Meat Co. v. McDonald [1963] S.R. (N.S.W.) 423 Sup. Ct. of N.S.W. in Banco per Brereton J, at p. 427. See further section 10C infra. 90. Co. Litt. 271a; cf. Kitto J, in Allen v. Roughley (1955) 94 C.L.R. 98, at pp. 139-40.

91. Co. Litt. 2a.

92. Jacobs v. Revell [1900] 2 Ch. 858; Sale of Goods Act 1979, s.12(1), which in our submission does not alter the effect of $s .12$ of the Act of 1893 . 
the limitation period, even though it be prior to ours, have any greater success; for again any wrong has been done not to the challenger, but only to the third party, from whom the chattel has been converted or against whose interest the possession of the land is adverse. This is the explanation of the possessor's ability, referred to above, ${ }^{93}$ to rely on a jus tertii; for, as we explain in the Tail hereof, $j u s$ in this context is not a title to property, but a right of action whereof the third party's title is the justa causa. Thus the plea of jus tertii is really no more than a plea of misjoinder of parties and once more the substance of the law is found "secreted in the interstices of procedure". ${ }^{94}$

Nonetheless the buyer's ability to remain in possession of the land and chattel until challenged by someone with title thereto is an interest which he has derived from us and which is his property. He can defend it, and claim the assistance of the courts, against those who, by force and thus wrongfully, seek to dispossess him of it. ${ }^{95} \mathrm{He}$ can transfer and continue it, e.g., by sale, ${ }^{96}$ by gift inter vivos, ${ }^{97}$ or by devise. ${ }^{98}$ Furthermore his possession and ours (for his is derived from ours) will be evidence of title in him sufficient to defeat a usurper not claiming through a third party, whose possession was prior to ours, or a squatter or a finder not pleading the right of the third party, to whom our possession was adverse. But the buyer will be

93. In the text at nn. 66, 67 and 68 ; and see Buckley v. Gross (1863) 3 B. \& S. 566, where a finder larvfully deprived of a chattel, whereof the owner was known, could not recover it from a third party subsequently in possession, for which reference we are indebted to an anonymous donor, whose information was passed to us by Dr. Reynolds of Worcester College, Oxford. Our donor, however, has objected: "The principal argument against this thesis is that we should have to hold that possession is no longer a root of title." Our answer is that possession was never a root of title, but only evidence of title: see the text at and about and n. 36 supra and Maitland, supra n. 5, at p. 334. The only root of title is acquisition by lawful occupancy - see the text following $n .83$ supra, or a title created by operation of law - see the text preceding and following $\mathrm{n} .79$ supra, or a 'commencement of title' deemed a good root of title by statute: Law of Property Act 1969, s.23.

94. Maine, Early Law and Custom, p. 389, quoted in Paton's Textbook of furisprudence 4th ed. (1972), p. 591. Another way of putting it is as did Brereton J, in OxfordMeat Co. v. McDonald, cited in n. 89 supra, at p. 427: "To sum it up, a right to possession in a third party is relevant if it demonstrates that the claimant has none."

95. Davison v. Gent (1857) 1 H. \& N. 744, at pp. 750-1 per Bramwell B, presumably for the sake of preserving the peace and to prevent the tortfeasor's taking advantage of his own wrong - hence, presumably, the reference to "ouster" in Oxford Meat Co. v. McDonald, cited in n. 89 supra, at p. 427 and see further the text at $\mathrm{n}, 9(2)$ infra; but entry by one with jus intrandi with no more force than is reasonably necessary is not a tort against the one in possession: Hemmings v. Stoke Poges Golf Club [1920] 1 K.B. 720 (C.A.).

96. Sale of Goods Act 1979, s.12(1) and (3). This and the next two examples illustrate the distinction made in Co. Litt. 3b between "purchase by conveyance or title." "Purchase" itself is distinct not from 'gift' but from 'wrong', on which see n. 72(2) infra.

97. Mt. Carmel Investments v. Peter Thurlow [1988] 3 All E. R. 129, for which reference we are indebted to the same anonymous donor and intermediary as are referred to in $\mathrm{n} .93$ supra. To the donor this case seems "a clear decision that the interest of the modern disseisor is not a fee simple by wrong. If his possessory title might pass by being given up to another quite informally, it was something else." We argue simply, but nonetheless respectfully, that no formality was needed because ex hypothesi there was no title to be transferred: see $n$. 2(2) infra. With Nicholl LJ's adoption at p. 135h-j of the summary in Megarry $\&$ Wade at p. 1036, we have no quarrel save, with respect, as regards part of paragraph (c), on which see n. 86 supra and which was not relevant to the decision. See further the text at and n. 3(2) infra. 98. Asher v. Whitlock (1865) L.R. 1 Q.B. 1. 
vulnerable to that claim or plea thus made. For his estate or interest is but naked possession $^{99}$ and is not lawful ${ }^{l}$ and will not become so until, by the lapse of the limitation period, he obtains title. ${ }^{2}$ Of course, in the meantime ${ }^{3}$ or thereafter, he himself may be dispossessed.

Once it is seen that one may be the owner of an interest in goods without having a title to that interest, so that the interest is purely possessory, and once it is seen that the usurper of an interest, being unable to qualify his wrong, is deemed to own (albeit by mere 'naked possession') all that (though no more than) he has usurped and thus generally a fee simple in land or a general property in goods (albeit 'not a lawful fee' nor a lawful property), two further perceptions are possible: First, Chalmer's wording of section 25(2) of the Sale of Goods Act 18934 "was directed to giving protection to those who had dealt in good faith with factors or agents, to whom goods, or documents of title to goods, had been entrusted, to the extent that the rights of such persons should (so far as provided) override those of the owner

99. Lord Chief Baron Gilbert's Tenures, p. 21, cited in Butler's note to Co. Litt. 238a which has afforded us our only sight of the relevant passage; see further section $10 \mathrm{~B}$ infra.

1. Co. Litt. 2a. That "interest" includes "estate" appears ibid. 345b.

2. See n. 35 supra. For he has no title in the meantime: Asher v. Whitlock (1865) L.R. 1 Q.B. 1, at pp. 5 and 6 per Cockburn CJ. This is so, despite the assertion of Megarry $\& W$ ade to the contrary, op. cit., $p$. $107, n .70$ and despite among the judges the laxity of language, against which we quoted Hargreaves' warning in the text at n. 3 supra. For none of the cases, whereon they purport to rely, holds that possession, short of prescription or the limitation period, is more than evidence (by raising a presumption) of title and, in particular: what is said in n. 61 supra, of Mellor J's judgment in $A$ sher is presumably true also of the judgment of the Privy Council in Perry v. Clissold [1907] A.C. 73, where A sher is approved and the contrast is drawn between mere "possessory title" and "absolute title"; while in Oxford Meat Co. v. McDonald, cited in n. 89, supra, at p. 427 Brereton J refers to the adverse possessor's "inchoate title". In Allen v. Roughley (1955) 94 C.L.R. 98 the judgments must be read subject to the specific remarks of Dixon CJ, at p. 108, lines 1-14 and p. 110, of Williams J, at p. 118, lines 9-11, of Fullagar J, at p. 128, lines 1-12, of Kitto J, in the whole paragraph which begins at p. 139 and of Taylor J, at p. 145 in the first 5 lines of the last paragraph. In Nair Service Society v. Alexander A.I.R. 1968 S.C. 1165 per Hidayatullah J, one must have regard to the use of "prima facie" twice at p. 1173 and in Oxford Meat Co. v. McDonald to the words including and following "deemed" at p. 426, while Spark v. Three Minute Car Wash (1970) 92 W.N. (N.S.W.) 1087 is but an avowed following and application of Asher v. Whitlock, Perry v. Clissold, Allen v. Roughley and Oxford Meat Co. v. McDonald. Cf. Hargreaves, supra n. 2, p. 383. As Wiren, supra n. 1(1), p. 152 said: "To use an ancient phraseology, the defendant is usually in by title or by tort, and there is little need for other classification." $C f$. Co. Litt. 2a, quoted in $\mathbf{n} .72$ infra.

3. In this event, whether or not he takes action against the usurper, time will continue to run against the party originally dispossessed, because the new usurper possesses, albeit adversely, the very interest which we ourselves acquired by our usurpation, or squatting, or finding and then sold. Thus the new usurper can be challenged by our buyer at any time before the limitation period, calculated from the time of the new usurpation, has expired - per Nicholls LJ, supra n. 97, at p. 135f-h, but by the party, whom we dispossessed, only before the expiry of the limitation period calculated from the time of our taking - ibid. at p. 132e-f. See also n. 86 supra.

4. More or less reproduced as s.25(1) of the Act of 1979. It read: "(2) Where a person having bought or agreed to buy goods obtains, with the consent of the seller, possession of the goods, or of the documents of title to the goods, the delivery or transfer by that person, or by a mercantile agent acting for him, of the goods or documents of title under any sale, pledge or other disposition thereof, to any person receiving the same in good faith and without notice of any lien or other right of the original seller in respect of the goods, shall have the same effect as if the person making the delivery or transfer were a mercantile agent in possession of the goods or documents of title with the consent of the owner." 
who had so entrusted the goods or documents of title to the factor or agent. There is not the slightest indication in the statute that it was intended to take so radical a step as to depart (except in the limited circumstances ... indicated) from the cardinal principle of the law of property in chattels embodied in the Latin maxim nemo dat quod non habet, so as to enable a factor or agent, entrusted with goods by a thief or a purchaser from a thief, to give a good title to a bona fide purchaser from him." 5 Secondly, the oft-repeated ${ }^{6}$ criticism of Chalmers' wording is unwarranted.

At the end of the sub-section the expression 'owner', rather than 'seller', was used because the expression forms, not part of the description of the sale, for the effect whereof the draftsman was making provision, but part of the unreal condition to which that effect was being equated. Clearly, the principal of the hypothetical mercantile agent was supposed to be 'the owner'. But, equally clearly, 'the owner' could refer only to 'the owner' of the subject matter of the relevant sale or agreement to sell. In the case of a thief or a purchaser from a thief that interest would be the general property in the goods unsupported by title. Therefore the owner of an interest in the goods, which amounted to the general property with title, clearly would not be affected by such a transaction as was envisaged in the sub-section.

$A$ fortiori, once it is seen that possession is a concept as much to be distinguished from property as from title, it is possible to perceive that possession, which is neither supported by title in the possessor nor adverse to the interest of another, will not constitute property in the possessor. Therefore a bailee or an agent need not have any property in the goods of the bailor or the principal. A mere agent cannot sue in respect of any injury to goods in his care; for the only possession is of, ${ }^{7}$ and the only injury is to, the principal. If a mere agent's apparent possession be challenged, he can only rely on the possession of his principal. On the other hand: the capacity of a defendant in possession to plead jus tertii explains the bailee's capacity to defend his own possession against all except the bailor or one with evidence of title superior to the bailor's; while the limitation, of the capacity to plead jus tertii to a defendant in possession, explains the bailee's right to sue for deprivation of, or damage done, to goods in his possession. ${ }^{8}$ The tortfeasor cannot plead the jus of the bailor, even if as a result of the tort he has gained possession of

5. Per Lord Goff of Chieveley in National Employers Insurance Ltd. v. Jones [1990] A.C. 24 pp. $58 \mathrm{H}-59 \mathrm{~B}$ (H.L.).

6.E.g., judicially, per May LJ, ibid. C.A., at p. 39E and, academically, by Battersby and Preston, supra n. 23, p. 284 ad init.

7. National Mercantile Bank v. Rymill (1881) 44 L.T.N.S. 767 (C.A.), in our submission, demonstrates our proposition in the converse situation. We do not share the doubts concerning this case expressed in R. H. Wills \& Son v. British Car Auctions [1978] 1 W.L.R. 439 (C.A.), at p. 443C, per Lord Denning MR, and at p. 444B per Roskill LJ, both of whom founded on Hollins v. Fowler (1875) L.R. 7 H.L. 757 H.L.(E); for in the last mentioned case it was expressly (and unanimously) held that the defendants had acted as principals: ibid. at p. 794 per Lord Chelmsford, at p. 796 per Lord Cairns LC, at p. 798 per Lord Hatherley and at p. 800 per Lord O'Hagan.

8. The Winkfield [1902] P. 42 (C.A.). 
the goods; for that would be to enable him to take advantage of his own wrong. Hence metaphorically (or, perhaps, laxly) "against a wrongdoer, possession is a title", ${ }^{9}$ which can be defeated by a jus tertii only if the tortfeasor claims under it himself. ${ }^{10}$ There is no need to postulate ${ }^{11}$ a special property in every bailee, any more than in a licensee of realty. ${ }^{12}$ This concept can properly be confined to such as those with rights of security, whether lienors or pawnees, ${ }^{13}$ who need it not to be able to resist the title of the lienee or pawnor, which they could do by virtue of their contract, but so that they may, at law, assign the security. ${ }^{14}$

\title{
8. The quarry pursued (into Succession)
}

In the light of the foregoing, let us return to executors' assents. ${ }^{15}$ Blackstone said: ${ }^{16}$

\begin{abstract}
"[The] bequest transfers an inchoate property to the legatee, but the legacy is not perfect without the assent of the executor: for if I have a general or pecuniary legacy of $100 l$, or a specific one of a piece of plate, I cannot in either case take it without the consent of the executor. For in him all the chattels are vested; and it is his business first of all to see whether there is a sufficient fund left to pay the debts of the testator: the rule of equity being, that a man must be just, before he is permitted to be generous." 17
\end{abstract}

A pecuniary or a general legacy is one which may or may not be part of the

9. Per Lord Campbell CJ, in Jeffries v. G.W.R. (1856) 5 E. \& B. 802, at p. 805. Nullus commodum capere potest de injuria sua propria appears in Co. Litt. $148 \mathrm{~b}$.

10. The Winkfield, supra n. 8(2) at p. 54 per Collins MR. See further, ibid, at p. 56 per eumdem. Likewise a bailee, being estopped from denying the bailor's title, can plead ius tertii only with the express authority, and on behalf, of the tertius.

11. As, e.g., in Schmitthoff, The Sale of Goods (1966), p. 219. As to judicial controversy on the point, see n. 14 infra.

12. Marchant v. Charters [1977] 3 All E.R. 918 (C.A.), at p. 922g, per Lord Denning MR.

13. See n. 51, supra.

14. Bull v. Faulkner (1848) 2 DeG. \& Sm. 772 (lien); Donald v. Suckling (1866) L.R. 1 Q.B. 585 (pledge). Quaere: a special property conferred by hire (as appears from Lee v. Atkinson \& Brooks (1699) Yelv. 172 , though a simple finding of a right of possession in the plaintiff would have been enough to justify the decision); but at most, in our submission, despite the breadth of that judgment, only if the bailee has the right to assign the right to use the goods. For in Roberts v. Wyatt (1810) 2 Taunt. 268 both Mansfield CJ, and Chambre J, were at pains to say that a simple bailment, albeit pursuant to a contract, conferred not a "special", but only a "temporary", property which surely cannot be distinguished from a mere right to possession. Even in Gordon v. Harper (1796) 7 T.R. 9 (an unsuccessful action of trover against a sheriff by a landlord in respect of the seizure of his goods from the tenant of furnished premises) there is no mention in the judgments of a special property in the tenant, but only of the landlord's lack of an immediate right to possession. But contra Watson B, in Sands v. Shedden (1859) 1 F. \& F. 556.

15. See the text following n. 16 supra.

16. 2 Com. 512. The emphases in the quotation are the author's.

17. As Blackstone here implies, at common law the power to assent applied only to personalty. On the reason for this and on the history of the changes worked by statute on the relationship between assents and testamentary gifts, see a further article by Stebbings, "The Common Law Power of Assent over Personal Property", [1990] Conv. 257. Our concern in this piece is with the current position, as to which see the text at $\mathrm{nn} .42(2)$ and 48(2) infra. 
testator's property. Thus a gift of $£ 100$ money or $£ 100$ stock does not imply that the estate includes either money or stock. If it does not, the executor must raise the money or buy the stock. A specific legacy is a gift of a particular article. ${ }^{18}$ To adopt the parlance of the Sale of Goods Act: a general or a pecuniary legacy is a disposition either of future goods ${ }^{19}$ or of existing but unascertained goods; ${ }^{20}$ and a specific legacy a disposition of specific goods. ${ }^{21}$ Moreover, Blackstone makes it plain that, in the same parlance, a legacy is a conditional disposition, ${ }^{22}$ the condition being the payment of the testators' debts (including the funeral and testamentary expenses $)^{23}$ which we have earlier learnt to call the clearance of the estate. ${ }^{24}$ It is through the recognition of this condition that the function of assents can be discovered.

As the Sale of Goods Act 1979 demonstrates: unless and until the condition of a transfer of property in an interest be fulfilled, the transfer cannot take effect; but once the condition be fulfilled then, if the subject matter of the transfer be identified and agreed upon, the transfer takes effect without more ado; and hence the provisions of section 18 rule 1 of the Act. ${ }^{25}$ The assent of the executor or of the administrator cum testamento annexo is his acknowledgment that, apart from the subject matter of the testamentary gift, there are assets in the estate sufficient to meet the debts and expenses; and it is irrevocable. ${ }^{26} \mathrm{Hence}$, if the subject matter of the gift be specific, the property in that subject matter passes on the clearance of the estate or on an earlier assent. Furthermore, in the case of any specific chattel to which a documentary title does not pertain, the representative's assent, whether express or implied, is enough to transfer the title, so as to enable the donee to sue at law for its recovery, whether from the representative ${ }^{27}$ or a stranger; for, the property being disposed of by the will, ${ }^{28}$ the assent can benefit only the true donee,

18. Bothamley v. Sherson (1875) L.R. 20 Eq. 304, at pp. 308-9 per Jessel MR. See also re Elcom [1894] 1 Ch. 303 (C.A.).

19. Defined in the Act of 1979 , s.61(1).

20. As envisaged ibid., s.18 r.5(1).

21. Supra n. 19(2).

22. As envisaged, ibid..

23. 2 Com. 511.

24. See the text following $\mathrm{n}$. 15(1) supra.

25. "Where there is an unconditional contract for the sale of specific goods in a deliverable state the property in the goods passes to the buyer when the contract is made ..." Even in gifts, there must be agreement: $\operatorname{Re}$ Wimperis [1914] 1 Ch. 502.

26. Noell v. Robinson (1681) 2 Vent. 358.

27. Barton's Case (1677) 1 Freem. 289; Doe d. Lord Saye and Sele v. Guy (1802) 3 East 120.

28. So that an administrator c.t.a. has power to assent - see n. 17(1) supra - and so that, if the gift be unconditional, so must the assent be, even if the representative purports to attach a condition: Westwick v. Wyer (1591) 4 Co. Rep. 28a. 
even if the chattel be delivered to the wrong person. ${ }^{29}$ But, if the gift be not of a specific asset, even one without a documentary title thereto pertaining, an assent does not give the donee the right to sue at law. For a will can no more dispose of property in unascertained goods, than can a contract of sale. ${ }^{30}$ In the case of a general legacy or of a share on a partial intestacy, therefore, the donee must have recourse to equity, if payment be not voluntary. ${ }^{31}$

Mention of documentary title brings us back to two distinctions previously drawn: between assets with, and assets without, documentary titles; ${ }^{32}$ and between express assents and assents to be implied from the representative's conduct in clearing the estate. ${ }^{33}$ The implication arises not simply out of the common law's general lack of formality regarding personalty, but its combination with the maxim, omnia praesumuntur rite et solenniter esse act ${ }^{34}$ for from an assent's being a mere, but requisite, admission that the subject of a gift is not needed for the clearance of the estate it follows that, on a clearance, an executor's duty to allow the will to take effect involves an obligation to assent. Assents so implied are effective to pass title only to specified assets without documentary title, such as personal chattels, ${ }^{35}$ bearer securities and cash in hand or at bank. ${ }^{36}$ As regards them, no further legal formalities, than the clearance itself, are needed for the passing of title. Only procedural steps remain to be taken, such as delivery, or instructing the bank manager; and such steps have nothing to do with title. It is otherwise if documentary title does exist, for example, in the case of registered stocks and shares where, after the clearance, there are required a transfer form and alteration of the register. In that case, (there being generally no prescribed form of an

29. Re West [1902] $2 \mathrm{Ch}$. 180. One, therefore, does not necessarily have to regard an assent, as was suggested by Kekewich J, when dealing with specific bequests of leaseholds in Re Culverhouse [1896] 2 $\mathrm{Ch} .251,253$, as "an exception from the general law that a man requires, in order to complete his title, something in the nature of a conveyance"; for, if the gift be specific, the will, once the condition is fulfilled by the assent, is the conveyance: see the text an $\mathrm{nn}$. 25-28(2) supra. The modern statutory requirement of a written assent in connexion with estates in land was presumably introduced because of the danger inherent in the doubts attendant on the informality of assents at common law, e.g., in Doe d. Hayes v. Sturges (1816) 7 Taunt. 217. Cf. the "Reasons for passing this Act" set out in the Statute of Frauds 1677 , the effect of the statute not to avoid, but to render unenforceable, contracts within its ambit and Equity's evasion of that effect. Even as regards a partial intestacy, one can argue that the will disposes of the property to the personal representative on a trust implied from the current statute of distributions ( $c f$. the text at $\mathbf{n} .45$ infra) and thereby justify the existence in that circumstance of the power to assent which is referred to in 17 Halsbury's Laws of England 4th ed. (1976), 1345.

30. Sale of Goods Act 1979, s.16.

31. Deeks v. Strutt (1794) 5 T.R. 690.

32. See the text preceding n. 36 supra.

33. See the text preceding n. 17(1) supra.

34. See n. 11(1) supra.

35. As defined in the Administration of Estates Act 1925, s.55.

36. Attenborough v. Solomon [1913] A.C. 76 (H.L.(E.)), as explained by Stebbings, supra n. 7(1), at p. 426. 
assent's expression $)^{37}$ by his submission to the company of the form of transfer from himself, as personal representative, to himself in some other capacity ${ }^{38}$ or to another legatee, the executor or administrator has given his express assent to his holding of the asset in his new capacity or to its being held by the other legatee.

In short: wherever a documentary title is required, obviously (to be valid) it must be complete; and so, in the case of an asset with documentary title one must have a document to transfer the title to a testamentary gift, i.e., to record the satisfaction (at the date of the document or previously) of the condition precedent to the passing of the property in an interest from the executor, who has proved, to the beneficiary, whether the beneficiary be entitled absolutely, or as a trustee, and whether the beneficiary be the same person as, or different from, the executor. Nothing more is needed even when the trustee is an executor who has not proved; for there is no need to see written assents (whether by an executor to himself as trustee or to beneficiaries, including himself, generally) as ever being more than such documentary records. In truth, in cases of documentary title can there be any room at all for implied assent? ${ }^{39}$ If there has been no previous express assent by the representative, ${ }^{40}$ the only assent is that expressed in the appropriate document. Thus do we justify the registration of the instrument of transfer of land wherewith this hunt began. Thus also do we, like Lord Wilberforce, pierce the mystery. ${ }^{41}$ For thus have we demonstrated that if there be documentary title there is no distinction, in the area of this discussion, between land and other assets because, since Re King's Will Trusts, ${ }^{42}$ it has been accepted that by the Administration of Trusts Act 1925, section 36(4), which has preserved, extended and, indeed (by its demand for writing), strengthened the requirement of the common law, a written assent is necessary to pass the legal title in land from a personal representative to a trustee, even when each is embodied in the same person.

Nonetheless, although the only effect of an assent, express or implied, by representatives who have cleared the estate, is to transfer the title (so that the title may follow the property in the relevant interest which, on the completion of the administration of the estate and its accomplishment of the condition precedent to

37. Doe d. Sturges v. Tatchell (1832) 3 B. \& Ad. 675. Thus where an asset has been specifically left to an executor upon trust, he has been held to have become the trustee of it when he has severed it from the rest of the estate: Phillipo v. Munnings (1837) 2 My. \& Cr. 309. Of course, he could also execute a declaration of trust.

38. And, probably (even when he takes as a trustee) in ostensibly a purely personal capacity, there being a prohibition on companies' recognition of trusts in their shares: Companies (Tables A to F) Regulations 1985 Schedule, Table A art. 5. as required by Companies Act 1985, s.360. We doubt that any regulations, which may be made pursuant to s.207 of the Companies Act 1989, will affect our characterization of stocks and shares.

39. But see Stebbings, supra n. $7(1)$, at p. 426 in the first sentence of the last paragraph.

40. Unlike, e.g., re Grovesnor [1916] 2 Ch. 375.

41. See the text at and n. 5(1), supra.

42. [1964] Ch. 542. A statement of the Common Law may be found in Halsbury's Statutes in the notes to the Administration of Estates Act 1925, s.8. 
the gift, was earlier and automatically transferred to the donee), ${ }^{43}$ yet in the case of a gift of a specific asset to which pertains a documentary title, unless the assent consist in or be followed by the appropriate piece of writing, even it does not give the donee the right to sue at law and the donee must have recourse to equity. This is so, not because the donee lacks the property in the asset, but because he lacks the justa causa possidendi on which alone a court of law can act. ${ }^{44}$ In these cases, however, a court of equity will recognize the representatives as bare trustees and will enforce the donee's call for the title to his property by compelling them to sign, seal (if necessary) and deliver the appropriate document. If a sole representative be himself the donee absolutely and beneficially, then presumably he may be trusted to look after his own interests and to follow the assent with that document. If he be the donee, but only as trustee, the cestui que truste may seek the help of equity to ensure that the subject matter of the trust is properly constituted and handled.

Once it is seen that an assent is essentially the acknowledgment of the fulfilment of a condition precedent to a disposition, it can also be perceived why, in the case of intestacy, there is no place for the operation of the doctrine of assent. For, $e x$ hypothesi in the case of intestacy, there has been no effective disposition. Although statutes of distribution on intestacy may have been described "as in substance nothing more than a will made by the legislature for the intestate", 45 in practice this description was just as much "a loose metaphorical term" as was 'statutory conveyance', when applied to the operation of the statutes of limitations. ${ }^{46}$ Neither the administrator nor the beneficiaries have ever derived their interests in the deceased's estate from the legislation. The administrator has always taken his from the grant ${ }^{47}$ and only from him have the beneficiaries taken theirs. They therefore

43. Admittedly in re King's Will Trusts [1964] Ch. 542, at p. 548 Pennycuick J, disapproved of the suggestion, "that where the personal representative is also entitled in some other capacity, for example, as trustee of the will, as beneficiary, or otherwise, to the estate or interest, he may come to hold the estate or interest in that other capacity without any written assent." But the proposition, as expressed by his Lordship, is compressed insofar as it lacks the necessary expansion set out in the text above at $n$. 25(1) and following n. 54; and, of course, if in the expression "estate or interest" his Lordship was including 'title', as presumably he must have been, seeing that he does not mention 'title' separately at all, his words do not affect our argument. On the other hand we claim support from those of Viscount Haldane LC, in Attenborough v. Solomon [1913] A.C. 76, at p. 83: "The transfer is not made by the mere force of the assent of the executor, but by virtue of the dispositions of the will which have become operative because of this assent." See further, 14 Halsbury's Laws (2nd ed.) 343 and 344, where is recognized the distinction between the "inchoate property" created by the bequest and the "title" which is transferred by the assent; and also re Cunliffe-Owen [1953] Ch. 545, at pp. 558-60, per Evershed MR, to the effect that the "right" (which his Lordship evidently uses in a sense different from Coke's) of a legatee, even a residuary legatee, is the same before and after the completion of the administration of the estate; for which last reference we thank Professor P. Jackson of Reading University.

44. We submit this sentence to comprise the same distinction and its point, as were made by Jenkins $\mathrm{LJ}$, in Re Rose [1952] 1 Ch. 499, at pp. 518-519.

45. Cooper v. Cooper (1874) L.R. 7 H.L. 53, at p. 66 per Lord Cairns LC.

46. See the text at and n. 81 supra.

47. Chetty v. Chetty [1916] 1 A.C. 603 at pp. 608-9 per Lord Parker of Waddington (P.C.). 
had, and apart from the 1925 legislation ${ }^{48}$ have, to have recourse to the means of transfer ordinarily appropriate to the property in question, namely, assignment, conveyance, delivery, or formal transfer. ${ }^{49}$

\section{The head ${ }^{50}$}

The revelation, that forty years after Hargreaves' complaint it remained right for Lord Wilberforce, like Hargreaves himself, to place the blame for the modern confusion and mystification, in what to Blackstone was a "rational science" 51 and a "rational entertainment", 52 on extra-curial writings becomes all the more depressing, when it appears that confusion has been worse confounded by judicial and academic reliance on textbooks and articles, which themselves sought to explain what were seen as ancient mysteries. But such reliance must necessarily have that result. The necessity flows not from some academic vice, from which the Courts are exempt, but from the very nature of language. It may be trite, but it is nonetheless apt, to quote from Hart: ${ }^{53}$
"Whichever device, precedent or legislation [or, we should add, discussion], is chosen for the communication of standards of behaviour, these, however smoothly they work over the great mass of ordinary cases, will, at some point where their application is in question, prove indeterminate; they will have what has been termed an open texture. So far we have presented this, in the case of legislation, as a general feature of human language; uncertainty at the borderline is the price to be paid for the use of general classifying terms in any form of communication concerning matters of fact. Natural languages like English are when so used irreducibly open textured."

That the position is still worse when dealing with matters of abstraction appears from inter alia his earlier discussion of normative language. ${ }^{54}$

In our respectful submission, it was this linguistic necessity and not his Lordship's denial of logic in the law, which justified the observations of the Earl of

48. See the text at and following n. 42(2) supra. It was only of the Common Law, untainted by modern Acts of Parliament, that Coke said, "Ratio est anima legis": Co. Litt. Epil. We therefore offer no defence or explanation for the illogicality of the statutory extension of the power to assent, in respect of real estate, to all administrators. Another flagrant example of how much ill is to be expected of Parliament in this regard may be seen in the reports of the debates on the Nullity of Marriage Bill, especially in 317 Hansard (Lords) at 809 and in 318 op. cit., at pp. 936-7.

49. See the text at and following and $n .17(1)$ supra. If the administrator does not do as he ought then, because the beneficiary has no title, recourse must be had to equity: fones v. Tanner (1827) 5 B. \& C. 542.

50. See Shorter O.E.D. (1984) sub nom. "Head" sb. III 6.

51. 2 Com. 2.

52. Ibid., at 44 .

53. The Concept of Law (1972), pp. 124 et seq.. The emphasis is the author's.

54. Ibid., p. 56. 
Halsbury, LC, in Quinn v. Leathem: 55

". . . that every judgment must be read as applicable to the particular facts proved, or assumed to be proved, since the generality of the expressions which may be found there are not intended to be expositions of the whole law, but governed and qualified by the particular facts of the case in which such expressions are to be found ... . a case is only an authority for what it actually decides."

But writings, such as this of ours and those of our distinguished predecessors, are not composed on the basis of "particular facts proved", nor do any of them actually decide anything. Since they cannot be so confined, neither should they be so respected, as are judgments; and hence "the dangers, well perceived by our predecessors but tending to be neglected in modern times, of placing reliance on textbook authority for an analysis of judicial decisions." 56

\section{A. The tail, ${ }^{57}$ its root (in the text of a Lord Chief Justice)}

Coke's formula, which we adopt so heartily, ${ }^{58}$ appears in his commentary on the word "right" in the following sentence of Littleton:

"In the same manner it is, where tenant in taile grant all his estate to another; in this case the grantee hath no estate but for terme of life of the tenant in taile, and the reversion of the taile is not in the tenant in taile, because he hath granted all his estate, and his right, \&c."

The commentary (in Butler's edition) reads:

"Right", fus, sive rectum, (which Littleton often useth) signifieth properly, and specially in writs and pleadings, when an estate is turned to a right, as by discontinuance, disseisen, \&c. where it shall bee said, quòd jus discendit et non terra. But (Right) doth also include the estate in esse in conveyances; and therefore if tenant in fee simple make a lease for yeares, and release all his right in the land to the lessee and his heires, the whole estate in fee simple passeth.

And so commonly in fines, the right of the land includeth and passeth the state of the land; as $A$. cognovit tenementa pradicta esse jus ipsius, $B$. $\mathcal{E} c$. And the statute $[a]$ saith, jus suum defendere, (which is) statum suum. And note that

55. [1901] A.C. 495, 506. Cf. the approach of Browne-Wilkinson VC, in Lonrho plc v. Tebbitt [1991] 4 All E.R. 973, at p. 979h (Ch.D.); affd. [1992] 4 All E.R. 280 (C.A.).

56. See the text at and n. 5(1), supra.

57. See Shorter O.E.D. (1984) sub nom. "Tail" sb.' 4.

58. At n. 56(1), supra. 
there is jus recuperandi, jus intrandi, jus habendi, jus retinendi, jus percipiendi, jus possidendi.

Title, properly, (as some say) is, when a man hath a lawfull cause of entry into lands whereof another is seised, for the which hee can have no action, as title of condition, title of mortmaine, \&c. But legally this word (Title) includeth a right also, as you shall perceive in many places in Littleton: and title is the more generall word; for every right is a title, but every title is not such a right for which an action lieth; and therefore Titulus est justa causa possidendi quod nostrum est, and signifieth the meanes whereby a man commeth to land, as his title is by fine or by feoffment, \&c. And when the plaintife in assise maketh himselfe a title, the tenant may say, Veniat assisa super titulum; which is as much to say, as upon the title which the plaintife hath made by that particular conveyance. Et dicitur titulus à tuendo, because by it he holdeth and defendeth his land; and as by a release of a right a title is released, so by release of a title a right is released also.

According to the Shorter Oxford Dictionary (1984) "discontinuance" meant, "interruption of a right of possession or right of entry, consequent upon a wrongful alienation by the tenant in possession for a larger estate than he was entitled to"; and "disseisin", "usually, the wrongful dispossession of the lands, etc. of another: since 15th c. not used of personalty". "Quod jus discendit et non terra" on our interpretation is, "That which descends as a right and not as a tenement", ${ }_{59}$ and " $j u$ suum defendere", "the right to defend his estate". According to the same dictionary "fine" meant, "compromise of a fictitious or collusive suit for the possession of lands; formerly in use as a mode of conveyance."

Thus we understand Coke to be defining 'right' as being something to be declared or enforced by the court (or, indeed, as a right to sue or a right of action) on proof of 'title', so that until the 'title' be challenged by some wrongdoing, actual or fictitious (including collusive), so as to give the parties loci standi and the court jurisdiction, there would be no 'right' but only 'title' ${ }^{60}$ Hence: "every right is a title, but every title is not such a right for which an action lieth" and a title is the cause of the right of possessing or, on converting the first possessive (or genitive) to an adjective, titulus est justa causa possidendi.

We have encountered the objection: ${ }^{61}$

"Coke's definition of title... cannot be relied upon very far for any purpose. He admits it to be only one of a number of senses in which the word could be taken and even in his day it was not very helpful."

59. Which for us conjures up notions of the early operation of the equitable doctrine of conversion and the early transmission of choses in action.

60. Cf. at least the heading of section 17 in Thayer's "Possession and Ownership", (1907) 23 L.Q.R. 175 and 314 at p. 328 .

61. The author of the objection is the anonymous donor referred to in nn. 93 and 97 supra. 
This was not the opinion of Blackstone, who quotes it in his Commentaries, ${ }^{62}$ itself a work of authority and evidently to be departed from only when it conflicts with earlier writings, notably those of Coke himself. ${ }^{63}$ Coke's admission that his was only one of a number of senses in which the word could be taken was subject to his assertion that his is its legal sense. Presumably, as Hargreaves had to do again later, Coke was urging on his contemporaries the "strict regard for the traditional terminology of the law", whence alone flows the simplicity and coherence of the rules of land law and from which even the 11 th edition of Coke on Littleton seems to have strayed in the note on folio $238(a),{ }^{64}$ where it is said that out of the Statute 37 H.VI 1 fall "the donees and feoffees of the disseisor, for they come by title though it is a defeasible one." But, if all titles are relative, a proposition from which the objector did not express dissent, every title is theoretically defeasible by a better; and the only true distinction of coming into property is Wiren's, ${ }^{65}$ "by title or by tort" as determined in each case and only between the parties to the litigation.

\title{
10B. The tail, its extension (in the text of a Lord Chief Baron)
}

The passage in Gilbert's Tenures, on which we rely so heavily, ${ }^{66}$ reads:

\begin{abstract}
"When any man is disseised, the disseisor has only the naked possession, because the disseisee may enter and evict him; but against all other persons the disseisor has a right, and in this respect only can be said to have the right of possession, for in respect to the disseisee he has no right at all. But when a descent is cast, the heir of the disseisor has ius possessionis because the disseisee cannot enter upon his possession and evict him, but is put to his real action, because the freehold is cast upon the heir."
\end{abstract}

It has been objected that our reliance indicates that we have not understood the passage. For, says the same objector as before:

"[i]f it be land that is in question, the rule of the old common law was that seisin, whether by right or wrong, gave the party seised an estate. If he were seised by wrong, this estate would be a fee simple. The disseisee was left with no more than a right, either of entry or of action. The title of the disseisor, and of those deriving title under him, was good against anyone save the

62. Op. cit. at and in $\mathrm{n} .84$ supra, at $\mathrm{p}, 195$. There is, of course, the valid point that, since Coke's formula makes title the cause of a right, he is earlier inconsistent in stating that every right is a title; for that is to equate effect with cause. But that inconsistency does not invalidate the formula. For Coke's meaning can be expressed adequately thus: "Every right is derived from a title; but every title does not give rise to such a right for which an action lies."

63. Reid v. Metro. Pol. Commr. [1973] Q.B. 551, at p. 559 per Lord Denning MR.

64. Which in the 19th ed. follows the quotation from Gilbert discussed in section 10B infra.

65. Which we paraphrase in the text at $\mathrm{n} .78$ and quote in $\mathrm{n}$. 2(2) supra.

66. Expressly in n. 99 and implicitly in n. 2(2), supra. 
disseisee, or those deriving title under him. This is the point which Lord Chief Baron Gilbert was making in the passage ... The distinction which he takes . . between a naked possession and that right of possession which will entitle me to recover in a possessory action even against one whose right is better than my own was rendered obsolete by the abolition of the real actions."

But the assertion, "that seisin ... by wrong gave the party seised an estate", which we do not dispute, leaves unanswered the question, whether or not that estate was supported by title, to which we should respond in the negative; and the assertion, that under the old law a disseisor's estate was always a fee simple, whether true or not, ${ }^{67}$ contributes nothing to the debate.

With all due diffidence and deference, the objector's implication, that under "the rule of the old common law" seisin was more than the fact of possession in circumstances whereof the law would take account for one or more of its purposes, whether adjectival or substantive, seems to be completely opposed to Maitland ${ }^{68}$ who supports his argument with many instances. Gilbert's example of the conflict between the disseisee and the heir of the disseisor is merely the converse of the example of the conflict of titles constituted by Palmer v. Palmer ${ }^{69}$ and of the operation of the presumption, omnia praesumuntur rite et solenniter esse acta, as reflected in the maxim, in aequali jure potior est conditio possidentis. ${ }^{70}$ As we understand it, a disseisee, whether he had or had not lost what Coke calls "entrie", could in a possessory action (made available for the preservation of public order) recover against a disseisor whose right was better than his own but who, having failed to take the proper proceedings, was a wrongdoer. However, in the passage cited by the objector Gilbert does not speak of the disseisor's heir recovering (but only, subject to the bringing of a real action by the disseisee, of his retaining) possession against the disseisee, nor of anyone at all recovering nor even (provided one were sued in the right form) retaining, possession against another "whose right was better than [one's] own." In other words, namely, those used by us, ${ }^{71}$ against the disseisor, who cannot be allowed to take advantage of his own wrong, "metaphorically, (or, perhaps, laxly)" the disseisee's "possession is a title", while against the disseisor's heir who has done no, but merely succeeded to the fruits of

67. It contradicts the modern view, which we set out in section $10 \mathrm{C}$ infra; but admittedly, for whatever reason, in Co. Litt. at 2a reference is made only to the fee simple.

68. Supra n. 5(1), especially p. 334; and see n. 58(1), supra.

69. See n. 29(1), supra.

70. See the text at nn. 10(1) and 11(1) supra.

71. In the text at n. $9(2)$, supra in reliance on Lord Campbell CJ. 
another's, wrong ${ }^{72}$ the disseisee must prove his title in the ordinary way. ${ }^{73}$ Thus explained, even Gilbert's use of ius is consistent with Coke's proposition, that "every right is a title". With respect, the objector's relation of the abolition of the real actions seems irrelevant to the argument. For " $[t]$ he forms of action we have buried, but they still rule us from [their] graves", 74 so that, even with our modern single form of writ we can still expect to see in the pleadings, which it initiates, reflections of the multiplicity and variety of its ancestors.

\section{C. The tail, its tip (in modern cases of adverse possession against leaseholders)}

Above, ${ }^{75}$ we cite Australian authority for the proposition that, if a usurper or squatter occupies land that is let, then, until the expiry, surrender or other determination of the lease, his possession is adverse only to the interest of the tenant, whose obligations to the landlord are not thereby affected (there being no assignment of the lease), so that time does not begin to run against the landlord

72. Our limitation of "wrong" is warranted by Co. Litt. 2a: "So as every man that hath a fee simple, hath it either by right or by wrong. If by right, then he hath it either by purchase or descent. If by wrong, then either by disseisin, intrusion, abatement, usurpation, \&c." The distinctions between the different types of wrong are drawn at 277a-b. Metaphorically Coke's use here of "right" is consistent with the passage at $345 \mathrm{~b}$ extracted in section $10 \mathrm{~A}$ (supra) and see the text following $\mathrm{n}$. 73(2), infra. 73. Wherein may be met the plea of ius tertii; for Gilbert CB's example is but the converse of that in the text at n. 66(1), supra.

74. Maitland, The Forms of Action at Common Law (cited in n. 58(1), supra), p. 1. In the fourth lecture he contrasts "possessory" with "proprietary", but he makes it clear that by the "proprietary" actions he meant the "real" included in Blackstone's definitions ( $3 \mathrm{Com} .117,118)$ which he notes as follows:

"Real actions, which concern real property only, are such whereby the plaintiff, here called the demandant, claims title to have any lands, or tenements, rents, commons, or other hereditaments in fee simple, fee tail or for term of life.

Personal actions are such whereby a man claims a debt, a personal duty, or damages in lieu thereof; and likewise, whereby a man claims a satisfaction in damages for some injury done to his person or property.

Mixed actions are suits partaking of the nature of the other two, wherein some real property is demanded, and also personal damages for a wrong sustained."

The emphasis on title is ours; and, because on p. 49 Maitland recalls only "the accepted definition of the words 'real', 'personal', and 'mixed' as applied to actions; meaning, that is to say, actions of which the result is the recovery of the thing or of damages or of both, respectively", we supplement him from Jowitt's Dictionary of English Law (1953) with its references to "personal actions, in which the plaintiff sought to recover a debt or damages from the defendant; real actions, in which he sought to establish his title [our emphasis] to land or other hereditaments; mixed actions, in which he sought only to establish his right of possession [our emphasis] to land."

Thus we consider it legitimate for us to assume that by "real action" Gilbert CB, means a writ of right and for us to mean (and to assume that the objector also means) by possessory action one of the possessory assizes, one of the writs of entry, or the writ of trespass de ejectione firmae. The irrelevance (asserted also by the objector) of whether or not the disseisee's right of entry (Coke's "entrie") had been removed ("tolled"), we have also deduced from p. 49 of Maitland's Forms of Action. The connexion between Co. Litt. 238a and the Lord Chief Baron's exposition, which Butler makes, is only that both deal with loss of the right of entry; for he appends the latter to Littleton's sentence, "The entrie of the disseisee is taken away."

75. In n. 89, supra. For the criticisms which led to this expansion of that note we thank Mrs. Cooke, and for his consideration of the result we thank Mr. Smith, both of Reading University. 
until the lease be determined. But, surely, as is implied by Lord Radcliffe ${ }^{76}$ and despite the difficulties caused by Lord Denning's use of the word 'title', ${ }^{77}$ it is also the ratio of Fairweather v. St Marylebone Property $\mathrm{Co}^{78}$ in which, on the tenant's surrender of the lease to the landlord after the expiration of the limitation period, the latter became entitled to eject a squatter, but which is criticized by Megarry $\mathcal{E}$ Wade. ${ }^{79}$ Its objection is that a tenant, who has himself "lost all power to eject [the squatter], .. . cannot ... confer any such power upon [the landlord]." But the tenant is not conferring any such power. It is the determination of the lease, the consequent merger of the leasehold with what had been the reversion and the resulting extinction of the only interest owned by the squatter, that entitle the landlord to evict him; and it matters not whether the extinction be effected by surrender, or by effluxion of time, or by forfeiture. Nor, in the case of unregistered land, but can there be any question but that the tenant retains the right to surrender; for the squatter, having taken possession of nothing that belongs to the landlord, can have no relationship with the landlord and, in particular, cannot replace the tenant in the landlord's affections. ${ }^{80}$

On the other hand, that its learned authors, to justify Spectrum Investment v. Holmes, ${ }^{81}$ rely ${ }^{82}$ on a 'parliamentary conveyance', though understandable in view of the trust created and maintained by section 75(1) of the Land Registration Act 1925 in the interim between the expiration of the limitation period and the registration of the adverse possessor's title, nevertheless, in our respectful submission, unnecessarily complicates matters. For, if there were a conveyance, then, until registration under section 75(3), one might expect the adverse possessor, through a beneficiary's normal obligation to afford his trustee indemnity, whether out of the trust estate, ${ }^{83}$ or perhaps personally, ${ }^{84}$ to find himself, albeit indirectly, liable on the covenants of the lease, in contrast to the position of the usurper of, or squatter on, unregistered land, as described below. Moreover, to characterize the effect of section 75(2), which entitles the adverse possessor after the lapse of the prescribed period to apply for registration of his proprietorship, as a 'parliamentary conveyance' is no more justified than the like characterization of the effect of the Limitation Act on unregistered land ${ }^{85}$ For that entitlement is no more than the reflection of the property which, with title, the

76. In his fourth complete sentence: [1963] A.C. at p. 536.

77. Ibid., at p. 545.

78. [1963] A.C. 510 (H.L.) wherein Taylor v. Twinberrow [1930] 2 K.B. 16 (C.A.) was approved and whence a dictum of Lord Denning, who was one of the majority, was followed in Tickner v, Buzzacout [1965] 1 All E.R. 131 (Ch.D.).

79. Op. cit., p. 1052.

80. See Shorter O.E.D. (1984) sub nom. "affection" sb. I.

81. [1981] 1 W.L.R. 221 (Ch.D.).

82. Op. cit., at p. 1053.

83. Stott v. Milne (1884) 25 Ch.D. 710 (C.A.).

84. Hardoon $v$. Belilios [1901] A.C. 118 P.C.

85. See the text at and n. 81(1), supra. 
adverse possessor gained on the extinction of the title of the dispossessed and on which we remarked above. ${ }^{86}$

To justify Spectrum and to render it, despite the dissimilar result, perfectly consistent with the decision of the House of Lords it is enough simply to give full effect to the policy of certainty and disclosure underlying the Land Registration Act. For a tenant who has (through the combined effect of adverse possession for the prescribed period, the possessor's application under section 75(2) and the Registrar's entry pursuant to section 75(3)) lost his title to a registered leasehold estate, of which the adverse possessor has become registered as the proprietor, can and must have nothing to surrender to the landlord because, pursuant to that policy, ${ }^{87}$ the registered estate must comprise every right, title, estate and interest of the lessee in, to and under the lease ${ }^{88}$ and none other than the registered proprietor may deal with that estate or any part of it; and it was on a vain attempt by such another ${ }^{89}$ that the later case turned.

However (following Tickner v. Buzzacott,${ }^{90}$ which involved forfeiture for nonpayment of rent, and subject to the possibility of estoppel), the adverse possessor may well, between the expiration of the limitation period and the expiry of the lease, be liable to the consequences of forfeiture of the lease for breach of a covenant against disposition, abandonment or the like and, almost inevitably, since "[h]e cannot pay the rent without the authority of the leaseholder", ${ }^{1}$ for its non-payment. This will be so, whether or not the leasehold estate constitutes registered land and, if registered, whether or not the adverse possessor be the registered proprietor thereof. For in the last instance the forfeiture will constitute a dealing by the landlord, who retains his recognition under the Act, not by the tenant, who has lost it. Furthermore, the forfeiture would be only against the tenant; for, there having been no assignment, the usurper, or squatter, and his successors have no interest in, or obligation under, the lease as a contract. Nevertheless, the forfeiture having terminated the only interest in the land to have been adversely possessed, the original adverse possessor or his successor may then

86. In the text at $\mathrm{n} .80(1)$.

87. And by virtue of ss.9, 11, 69(1) and (4) and 75 of the Act.

88. Save as regards those who claim by virtue of dealings of the registered proprietor (for their interests, even if unregistered, will be held by him on trust for them); and save as regards the unregistered interests which, by statute, are preserved, or even made overriding. Whatever may be the merits of Kenny's subtle argument in [1982] Conv. 201, its very subtleties would defeat the policy of the Act. The only support for the meaning which he attributes to $s s .69$ and 75 , that the adverse possessor becomes registered as proprietor of an estate subject to its being liable to surrender by the tenant, is the policy declared by the judges, whom he quotes, to keep the differences between registered and unregistered land to a minimum. But the policy of the Act itself must take precedence.

89. I.e., by the lessee after the squatter had become registered as the proprietor of the relevant leasehold estate.

90. N. 78(2), supra.

91. Per Lord Denning in Fairweather v. St Marylebone Property Co., n. 78(2), supra, at p. 547, unless in some way, which was not pursued in Tickner v. Buzzacott, ibid., it could be established that, in the case of registered land, for a tenant to withhold authority would be a breach of the trust created by the L.R.A. S.75(1). 
be evicted therefrom. Conversely, having no interest in the lease, so that there is not even privity of estate (let alone privity of contract) between the landlord and him, the adverse possessor is not personally liable to perform any of the covenants therein, whether or not they run with the land. ${ }^{92}$ On the other hand, because easements and restrictive covenants constitute exceptions from, ${ }^{93}$ and thus limitations on, the grant of the interest adversely possessed, the adverse possessor is bound by them. ${ }^{94}$

\section{Envoy}

A point divides us: Dr. Stebbings' first mentioned article asserted ${ }^{95}$ that, in the case of an asset with documentary title, before the written assent of an executor who is also a testamentary trustee, "the implied assent [arising out of the clearance of the estate] has the effect only of making the personal representative hold the asset in question on trust for himself as trustee under the will." To the Victorians among us, what we have written above ${ }^{96}$ (namely, that with documentary title there may be no room at all for implied assent and that, in the case of a gift to such an executor who has cleared the estate, a written assent merely causes the title to follow the property in the relevant asset which, by and since the clearance, has been vested in him as trustee) has the great attraction that, in its light, there is no apparent need for that trust. While Dr. Stebbings believes the trust to be possible, and that indeed it does exist, between the change of status, brought about by the clearance, and the transfer of title, effected by the written assent, Miss McClure and $\mathrm{Mr}$. Goldberg recoil from what they can see only as rejection of the rule in Selby v. Alston, ${ }^{97}$ that a person cannot be trustee for himself where the legal and equitable estates are commensurate. Dr. Stebbings claims there to be no rejection, because the two separate capacities of executor and trustee, even when combined in one human being, create two separate 'persons'. To Miss McClure and Mr. Goldberg this theory seems: unable to withstand Occam's Razor; to conflict with the doctrine which forbids the same person to be a plaintiff and a defendant in the same action, ${ }^{98}$ or even to be named twice on the record of an action, once in his personal, and again in a representative, capacity; ${ }^{99}$ and to be inconsistent with the vesting of the asset in the executor as trustee and the consequent expiry of the executorship quoad that asset. ${ }^{1}$ Though the point be sharp, the division is not, being blunted and bridged by the continuing correspondence of cheerful debate.

92. Tichborne v. Weir (1892) 67 L.T. 735 (C.A.).

93. Cf. Slade J, in re Bond Worth Lid. [1980] Ch. 228, at p. 253D.

94. Re Nisbet \& Potts' Contract [1906] 1 Ch. 386 (C.A.).

95. Supra n. 7(1), at p. 427.

96. In the text at and about n. 39(2), supra.

97. See n. 22(1), supra.

98. Re Phillips [1931] W.N. 271.

99. Hardie $\mathcal{E}$ Lane Ltd. v. Chiltem [1928] I K.B. 663, at pp. 700-1 (C.A.).

1. But the expiry is not entire: see Stebbings, "The Fallacy of Functus Officio in the Administration of Estates", [1990] Conv. 427. 